\title{
Satisfaction, HR, and Open Innovation in Tourism Sector
}

\author{
Adya Hermawati ${ }^{1, *}$, Nurwati Nurwati ${ }^{2}$, Suhana Suhana ${ }^{3}$, Zaky Machmuddah ${ }^{4}$ and \\ Shujahat Ali 5 (D) \\ 1 Magister Management Department, Postgraduate Program, University of Widya Gama Malang, \\ Jl. Borobudur No. 35, Malang 65125, Indonesia \\ 2 Management Department Faculty of Economics and Business, University of Halu Oleo, Kambu, Kendari, \\ Sulawesi Tenggara 93132, Indonesia; nurwati@uho.ac.id \\ 3 Management Department Faculty of Economics and Business, Universitas Stikubank, Jl. Trilomba Juang No. 1, \\ Semarang 50241, Indonesia; suhana@edu.unisbank.ac.id \\ 4 Accounting Department Faculty of Economics and Business, Universitas Dian Nuswantoro, \\ Jl. Nakula I No. 5-11, Semarang 50131, Indonesia; zaky.machmuddah@dsn.dinus.ac.id \\ 5 Department of Banking and Finance, Mirpur University of Science and Technology, Mirpur AJK, \\ Azad Jammu and Kashmir 10250, Pakistan; shujahat@must.edu.pk \\ * Correspondence: adya@widyagama.ac.id
}

Received: 13 October 2020; Accepted: 27 November 2020; Published: 5 December 2020

Abstract: The aim of this research paper is to depict the level of satisfaction and importance of Full expressions Micro, Small \& Medium Enterprises' (MSMEs)' human resources (HR) and the tourism sector community in East Java. The research was conducted on all aspects of HR in tourism sector MSMEs, among foreign and domestic tourists in East Java. The research is a quantitative and descriptive one. Primary data are used. The population of the research is HR in tourism sector MSMEs as well as domestic and foreign tourists. The sampling technique used is purposive sampling. Ten cities of high tourism potential were chosen. Determination of the sample size used the minimum criteria of a structural model that is between 100 and 200 units. In total, 200 tourism sector MSMEs were determined from ten tourism cities in East Java. From every tourism sector MSMEs, four employees and three tourists were taken. As a result, the entire research consisted of 800 employees and 600 foreign and domestic tourists. Importance performance analysis (IPA) was utilized as an analysis tool in this paper. The result indicated that each tourism resort, being a sample, has different findings. Batu City demonstrates a lack of transglobal leadership (TL). Malang, Kediri, and Blitar City demonstrate organizational citizenship behavior (OCB). Malang City lacks employment engagement (EE). Meanwhile, Pasuruan City and Blitar Regency are about human resources performance (HRP). For Pasuruan Regency, the variable of quality of work life (QWL) should be improved. For Sidoarjo Regency, sustainable tourism competitiveness (STC) should be paid attention. For Kediri City, the main variable that needs to be enriched is responsible marketing (RM). Overall, for the East Java region, the main variable that needs to be improved is RM. The findings obtained constitute a practical contribution for main tourism stakeholders to formulate relevant policies to cope with problems.

Keywords: MSMEs; human resources in tourism; IPA

\section{Introduction}

Human resources, as an intangible asset, can provide a contribution to the gaining of an organizationally competitive advantage. Skills and experts from human resources can be unique and difficult to imitate for competitors. Organizations wanting to win amid tight competition should focus 
on human resource upgrading. This is included in tourism human resource. To increase tourism sector performance, improving the quality of human resources is a strategic step.

Indonesia is a country with so many interesting tourism resorts. East Java, one of Indonesia's provinces, is considered an autonomous region with leading tourism destinations and is continuously building tourism competitiveness to improve regional income [1]. Perspective analysis of tourism destination, an indicator related to the success of the national development program in the field of sustainable tourism, can be achieved using empowerment as comprehensive development paradigm [2]. The number of foreign and domestic tourist's intention to visit East Java was portrayed in an in-stability condition at the point of achievement which was not yet significant [3]. This can be seen in Table 1, years 2014-2019, showing the number of foreign and domestic tourists coming to East Java. Besides that, Table 1 also shows the contribution of the tourism sector to the gross regional domestic product (GRDP) of East Java and its labor absorption. Therefore, the aspects and indicators of tourist enhancement are needed [4].

Table 1. Macro and Micro Conditions in the Tourism Sector in East Java in 2014-2019.

\begin{tabular}{cccccccc}
\hline \multirow{3}{*}{ Macro } & & 2014 & 2015 & 2016 & 2017 & 2018 & 2019 \\
& GRDP Contribution (\%) & 4.98 & 5.26 & 5.48 & 5.73 & 5.82 & 5.86 \\
& HR & 194,479 & 200,893 & 208,629 & 237,402 & 275,159 & 34,259 \\
\multirow{3}{*}{ Micro } & 2014 & 2015 & 2016 & 2017 & 2018 & 2019 \\
& Foreign Tourists & 300,909 & 463,358 & 612,412 & 618,615 & 690,509 & 830,968 \\
& Domestic Tourists & $39,680,000$ & $45,640,000$ & $51,470,000$ & $58,070,000$ & $65,630,000$ & $71,250,000$ \\
\hline
\end{tabular}

Source: Culture and Tourism Office, East Java 2020.

The solution is to empower MSMEs in the tourism sector [5]. Consequently, management, development, and empowerment of the tourism related sector MSMEs are expected to meet the needs and satisfaction of tourists. At the same time, it will improve the number of tourists coming. In turn, the condition will significantly impact on communities' welfare.

A brief analysis of quantity of MSMEs in East Java in all sectors shows the growing number of HR. The number of MSMEs was 6,825,931 while number of MSMEs' HR was 11,117,439 in 2019. It is more specific that $45 \%$ of existing MSMEs in East Java with a total number of HR reaching up to 4,550,200 is the tourism sector. Such conditions implied that MSMEs in the tourism sector play a pivotal role in increasing in the number of domestic as well as foreign tourists.

Implementation of aspects of HR related strategy in MSMEs in the tourism sector is estimated to be able to serve entire aspects of tourism because of its favorable characteristics, unique and not possessed by others [6]. A willingness to serve other people is considered as added value needed by HR in the tourism sector. Thus, HR in tourism sector MSMEs has a potential intermediation function [7]. Hermawati [8] identified the phenomenon of weak "business volume" of MSMEs in the tourism sector. Solution to the problems include revitalizing HR strategy by optimizing employee performance, HR training \& development, HR planning and integrated human resource performance. One of basic problems in tourism sector MSMEs is the phenomenon of HR [9]. Thus, improving quality of human resource will be urgent to do to increase the effectivity of organization [10].

From the description above, it is highly relevant to change the role of HR today. A humanistic perspective management approach places HR as a central factor. This will contribute to the gaining of a competitive advantage [11]. Thus, it is relevant to address critical issues of human resources for the tourism sector MSMEs in optimizing the level of performance [5]. As the focus of achievement, it is important to develop a model of responsible tourism marketing from a human resources aspect to improve the competitiveness of sustainable tourism in East Java. Findings from this study focus on scientific development of a strategy for HR and marketing [12]. Further, the research findings will contribute to the sustainable tourism sector in East Java.

After all, the aim of the research is to get a clearer depiction of the level of satisfaction and importance of MSMEs' human resources (HR) and the tourism sector community in East Java. 
The findings will provide an important contribution to the main tourism stakeholders, especially for culture and tourism office to make many needed actions.

The rest of the article will cover a literature review concerning human resource management and marketing management in Section 2. Section 3 presents a method of the research. It will be about the kind of the research, population and sample of the research, analysis tool used. Section 4 is concerning result of the research. Meanwhile, a discussion of the research is given in Section 5. Section 6 provides a conclusion of the research containing limitations and a future research agenda.

\section{Literature Review}

\subsection{HR Management}

Previous research findings have become the inspiration for conducting the current research. Empirical results from researches of [5] supported theories from [13] which stated that if the employees' needs are fulfilled, employees will be satisfied, work excellently, are more committed, with the implications of optimal individual performance and contribute to organizational performance. [14] analyzed and found the effect of QWL to employees' performance and work satisfaction. Results of researches show that QWL has an effect on work satisfaction and contributes greatly to optimal employee performance, then contributes to organizational performance. As [15] stated that managers of middle level have high participation but do not have high performance. Hense [16] stated that there is relevant weak relationship between work participation and employees' performance. So, [17] indicated that impact of employees' work participation on individual performance gives contribution to organizational performance. Researches by $[18,19]$ supported theories of [20] that work participation leads to one's performance. The existence of a favorable relationship between work participation and performance provides an impact on employees' and organizational performance.

Theories of [21,22] postulated the effect of OCB on individual performance. This is supported by the researches of $[23,24]$, stating that employees with OCB have a significant and positive effect on employees' performance. Hereby, [25] identified that there is an influence of leadership on the level of employees' work participation. Research by [26] specified that there is no favorable relationship between leadership and work participation. Researches by [27] stated that there is a positive relationship between leadership behavior and individual performance. Results of researches by [28] elaborated that employees' performance will be influenced by levels of leadership.

\subsection{Green Marketing}

The concept of green marketing is considered as a tool to protect the environment for upcoming generations, and this has a favorable impact on environmental security [29]. Also, in this context, [30] stated that green marketing would continue to grow in practice as well as in demand. As [31] conducted a research on sustainable tourism, an alternative form of tourism whereby the concept of green marketing is seen as a strategy that depicts mutual cooperation among suppliers and sellers, partners and rivals, in order to accomplish the sustainable development of environment throughout the system of value chain as the best possible solution for two main principles in obtaining long-term benefits, and positive contributions to the environment.

Meanwhile, Martínez, et al. [32] proves that the marketing of rural tourism must be seen as a means to achieve the development of rural tourism destination strategies, such as: long-term prosperity, tourist's satisfaction, maximum profits, extending the tourist season, neutralizing negative impacts on society, labor stability, support and diversification of economic activities.

A research by [33] explained that the tourism industry today shows an increasingly global, interdependent, uncertain, technological, and focused situation regarding issues of sustainability. Dynamics in market structure are also responsible for increasingly notable marketing strategies that cannot be considered as simple and only directed to the achievement of customer satisfaction [34]. In order to accomplish overall profits, but strategies of marketing are a reference in defining strategies 
related to business and providing optimum benefits for tourism destinations in a sustainable manner that will continue to grow in practice and demand. A sustainable strategy related to marketing or green marketing can be seen as a strategy that shows cooperation among suppliers and sellers, partners and competitors, in order to accomplish sustainable development linked to the environment.

For such reasons, this study analyzes the level of tourist's awareness of responsibility marketing as a key effort to create sustainable tourism and have formulation of model related to developing responsibility-marketing strategies. It is affirmed by [35] that, in tourism, the concept of marketing is an effort to identify the desires of tourists as well as for proposing tourism in accordance with the desires and wishes of tourists with the intention that tourism businesses can provide maximum service to tourists. Tourism marketing based on responsible behavior is often referred to as an effort to market sustainable tourism products. Sustainable tourism products are elaborated and defined as products that are responsible, i.e., socially and economically feasible, so that current product users can meet their needs without compromising fulfillment of the needs of future generations [36].

\section{Research Method}

This study was conducted in East Java in order to design and get a real depiction of the level of satisfaction and importance of MSMEs' HR and the importance of tourism sector communities in East Java for TL, QWL, job involvement (JI), OCB, HRP, RM, and STC. The use of the variables is based on the previous researches. The research is a quantitative and descriptive one. Primary data is used. The period of the research was 2019. The population in this study is: (1) the entire HR of MSMEs tourism sector, (2) foreign and domestic tourists in East Java. The sampling technique involved a purposive sampling of the sector related tourism MSMEs in East Java (10 cities tourism potential). The reason to choose 10 cities as a sample was due to their big potential for tourism development. Determination of sample size using the minimum criteria of a structural model is between 100 and 200, thus stipulating the number of tourism sector MSMEs from the 10 cities of tourism potential in East Java, such that one tourism sector MSMEs unit is composed of 4 employees and 3 tourists. Therefore, this research involved 800 employees and 600 foreign and domestic tourists. IPA is used to get a picture of the level of satisfaction and importance of MSMEs' HR and the tourism sector communities in East Java. For the purposes of analysis in this study, the answers are given on the following scores (see Table 2):

Table 2. Scores of Importance and Satisfaction.

\begin{tabular}{ccc}
\hline Scores & Level of Importance & Level of Satisfaction \\
\hline 5 & Very important & Very good \\
4 & Important & Good \\
3 & Fairly important & Fairly good \\
2 & Unimportant & Bad \\
1 & Very unimportant & Very bad \\
\hline
\end{tabular}

After calculating each attribute, the level of satisfaction and importance of MSMEs' HR and the communities of the tourism sector are measured by entering into each quadrant contained in the Cartesian diagram, which is shown in the following figure (see Table 3):

Table 3. Cartesian Diagram of IPA.

\begin{tabular}{cc}
\hline Quadrant A & Quadrant B \\
First Priority & Keep up the Good Work \\
\hline Quadrant C & Quadrant D \\
Low Priority & Excessive \\
\hline
\end{tabular}




\section{Result}

The following is elaboration of the measurement of IPA in various cities with all the variables shown in the Cartesian diagram. The aim here is to see the position of each variable in a priority concept. The measurement results of various variables are based on the level of interest of tourists and the level of performance of the MSMEs. The result can help the MSMEs to make improvements on the variables that are perceived important by tourists and MSMEs' employees.

\section{(1) Batu City}

The measurement of all variables in Batu City is described in the Cartesian diagram presented in the following figure, which centers on the $X$ and $Y$ axes. Axis $X$ is the average value of performance level and the $\mathrm{Y}$ axis is the average value of importance. The two axes form two perpendicular lines that intersect each other, dividing the Cartesian diagram into four quadrants (see Figure 1).

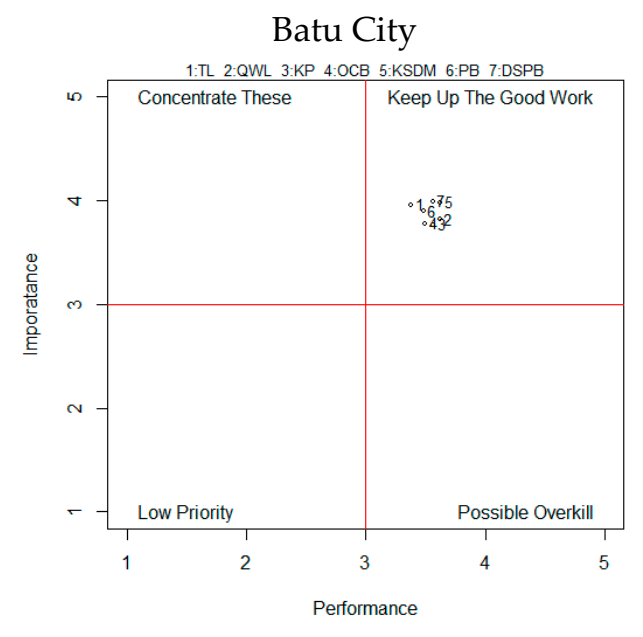

(a)

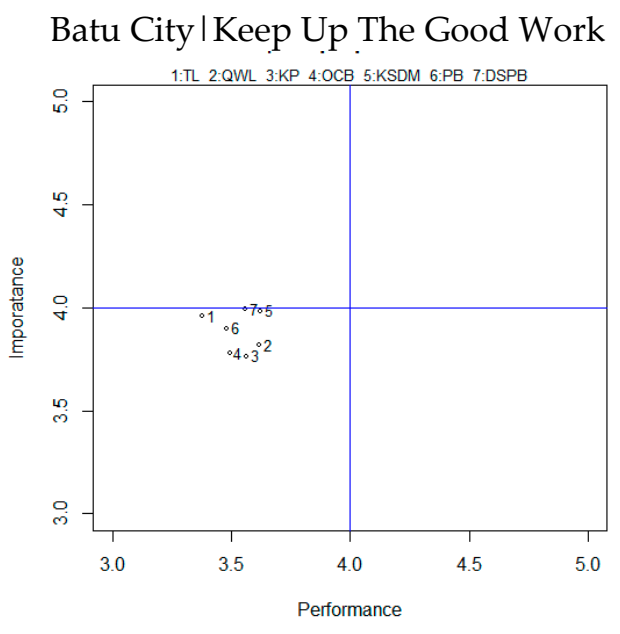

(b)

Figure 1. (a) IPA Cartesian Diagram of Batu City. (b) IPA Cartesian Diagram of Keep up the Good Work Quadrant of Batu City.

The Cartesian diagram above illustrates the expectations (importance) and reality (performance) with respect to the tourism sector MSMEs' employees and tourists in Batu City. Based on the diagram, it can be seen that TL, QWL, JI, OCB, HRP, RM, and STC are in quadrant II (Keep up the Good Work). This shows that the expectations and reality received by employees and tourists for all variables are equally high. Specifically, the expectation and reality values received by employees and tourists for all variables ranged from 3 to 4 . The difference between expectations and reality received by employees and tourists for each variable is shown in the following bar graph.

Based on the Figure A1 in Appendix A, it can be seen that the variable that has the biggest difference between expectations and reality received is the TL, which is equal to 0.58. Therefore, the main variable that needs to be improved is TL. Meanwhile, the variable that has the smallest difference between expectations and reality received is the variable of QWL and work engagement (WE) which is equal to 0.2. This shows that the QWL and WE received by MSMEs' employees and tourists in Batu City are in line with expectations.

\section{(2) Malang Regency}

The measurement of all variables in Malang Regency is described in the Cartesian diagram presented in Figure 2, which centers on the $X$ and $Y$ axes. Axis $X$ is the average value of performance level and the $\mathrm{Y}$ axis is the average value of importance. The two axes form two perpendicular lines that intersect each other, dividing the Cartesian diagram into four quadrants. 


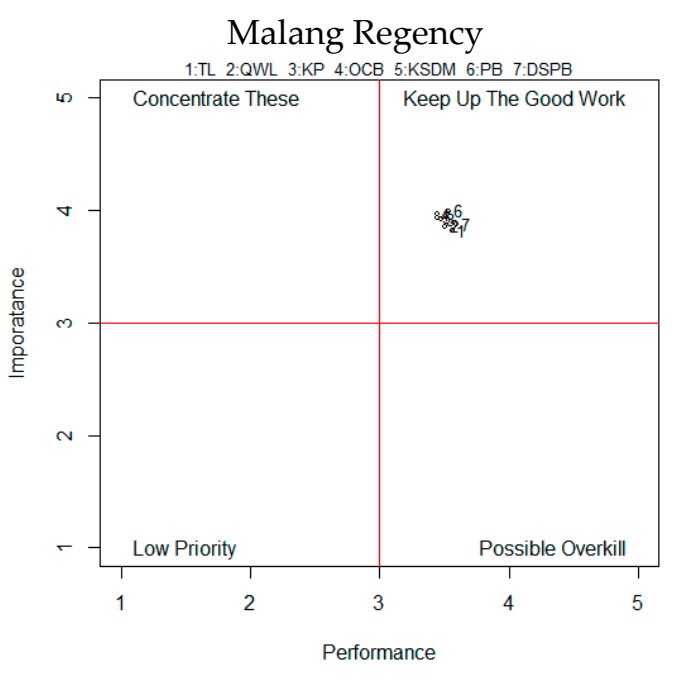

(a)

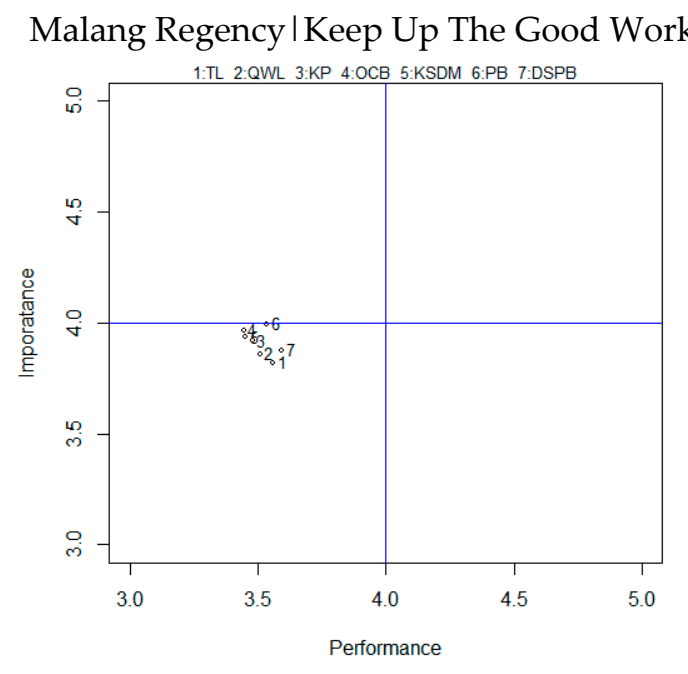

(b)

Figure 2. (a) IPA Cartesian Diagram of Malang Regency. (b) IPA Cartesian Diagram of Keep up the Good Work Quadrant of Malang Regency.

The Cartesian diagram above illustrates the expectations (importance) and reality (performance) with respect to the tourism Sector MSMEs' employees and tourists in Malang Regency. Based on the diagram, it can be seen that TL, QWL, JI, OCB, HRP, RM, and STC are in quadrant II (Keep up the Good Work). This shows that the expectations and reality received by employees and tourists for all variables are equally high. Specifically, the value of expectations and reality received by employees and tourists for all variables ranges from 3 to 4 . The difference between expectations and reality received by employees and tourists for each variable is shown in the following bar graph.

Based on the Figure A2 in Appendix A, it can be seen that the variable that has the biggest difference between expectations and reality received is the $\mathrm{OCB}$, which is equal to 0.52 . Therefore, the main variable that needs to be corrected is OCB. Meanwhile, the variable that has the smallest difference between expectations and reality received is the TL which is equal to 0.26 . This shows that TL received by MSMEs' employees and tourists in Malang Regency is in line with expectations.

\section{(3) Malang City}

The measurement of all variables in Malang City is described in the Cartesian diagram presented in Figure 3, which centers on the TL and HRP axes. Axis TL is the average value of performance level and the HRP axis is the average value of importance. The two axes form two perpendicular lines that intersect each other, dividing the Cartesian diagram into four quadrants.

The Cartesian diagram above illustrates the expectations (importance) and reality (performance) received by the tourism Sector MSMEs' employees and tourists in Malang City. Based on the diagram, it can be seen that TL, QWL, JI, OCB, HRP, RM, and STC are in quadrant II (Keep up the Good Work). This shows that the expectations and reality received by employees and tourists for all variables are equally high. Specifically, the expectation and reality values received by employees and tourists for all variables ranged from 3 to 4.2 . The difference between expectations and reality received by employees and tourists for each variable is shown in the following bar graph.

Based on Figure A3 in Appendix A, it can be seen that the variable that has the biggest difference between expectations and reality received is the JI, which is equal to 0.63 . Therefore, the main variable that needs to be improved is EE. Meanwhile, the variable that has the smallest difference between expectations and reality received is the QWL, which is 0.31 . This shows that the QWL received by MSMEs' employees and tourists in Malang City is in line with expectations. 


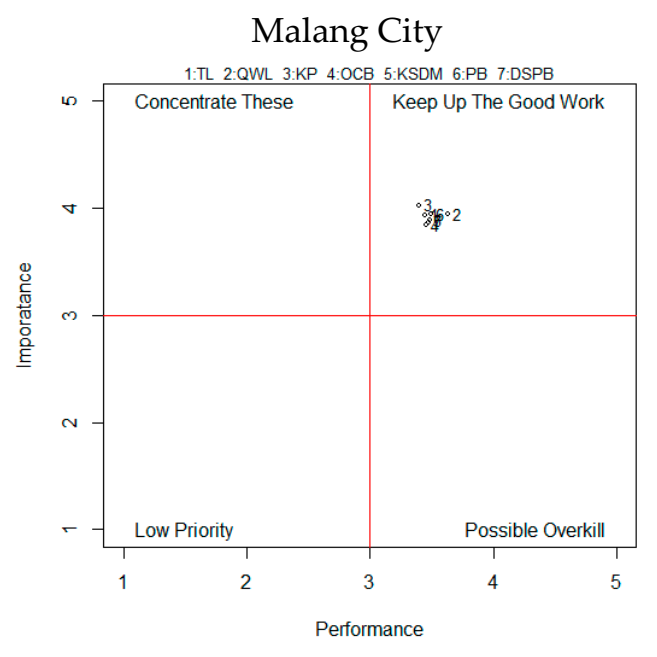

(a)
Malang City IKeep Up The Good Work

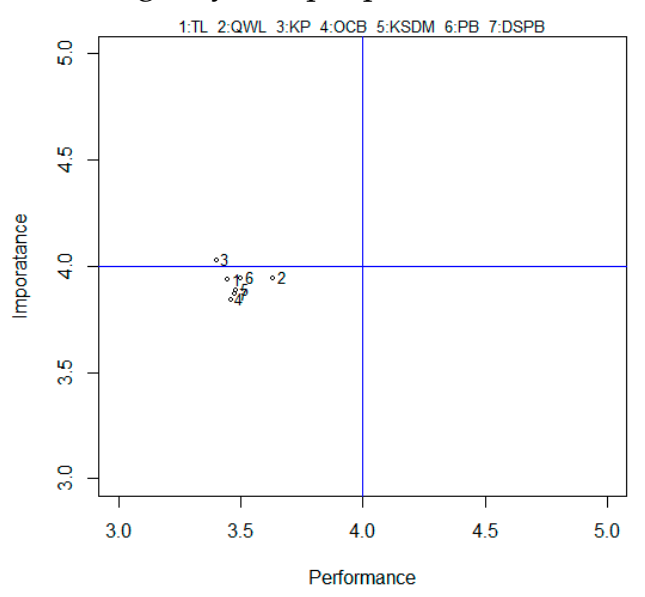

(b)

Figure 3. (a) IPA Cartesian Diagram of Malang City. (b) IPA Cartesian Diagram of Keep up the Good Work Quadrant of Malang City.

\section{(4) Pasuruan City}

The measurement of all variables in Pasuruan City is described in the Cartesian diagram presented in Figure 4, which centers on the TL and HRP axes. Axis TL is the average value of performance level and the HRP axis is the average value of importance. The two axes form two perpendicular lines that intersect each other, dividing the Cartesian diagram into four quadrants.

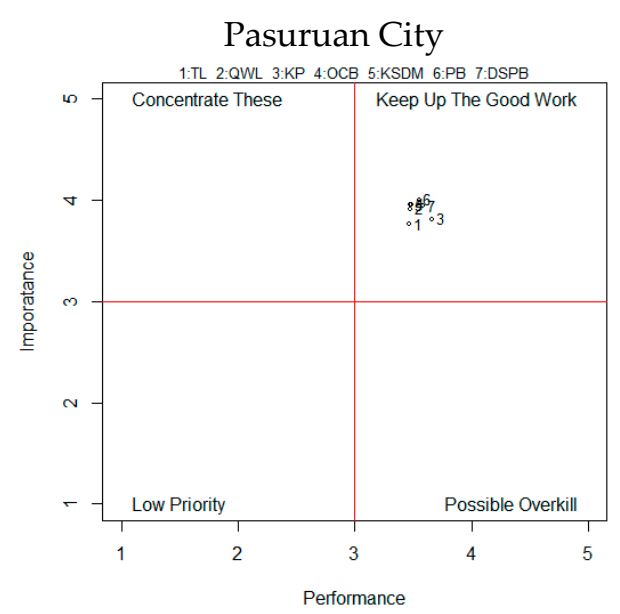

(a)

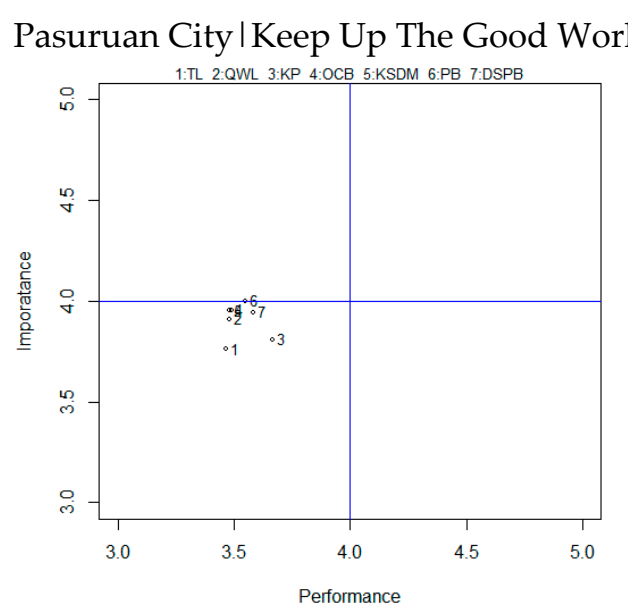

(b)

Figure 4. (a) IPA Cartesian Diagram of Pasuruan City. (b) IPA Cartesian Diagram of Keep up the Good Work Quadrant of Pasuruan City.

The Cartesian diagram above illustrates the expectations (importance) and reality (performance) received by the tourism Sector MSMEs' employees and tourists in Pasuruan City. Based on the diagram, it can be seen that TL, QWL, JI, OCB, HRP, RM, and STC are in quadrant II (Keep up the Good Work). This shows that the expectations and reality received by employees and tourists for all variables are equally high. Specifically, the expectation and reality values received by employees and tourists for all variables ranged from 3 to 4 . The difference between expectations and reality concerning employees and tourists for each variable is shown in the following bar graph.

Based on the Figure A4 in Appendix A, it can be seen that the variable that has the biggest difference between expectations and reality received is the HRP variable, which is 0.47 . Therefore, 
the main variable that needs to be improved is HRP. Meanwhile, the variable that has the smallest difference between expectations and reality received is the JI, which is 0.14 . This shows that WI, which is received by MSMEs' employees and tourists in Pasuruan City, is in line with expectations.

\section{(5) Pasuruan Regency}

The measurement of all variables in Pasuruan Regency is described in the Cartesian diagram presented in Figure 5, which centers on the TL and HRP axes. Axis TL is the average value of performance level and the HRP axis is the average value of importance. The two axes form two perpendicular lines that intersect each other, dividing the Cartesian diagram into four quadrants.

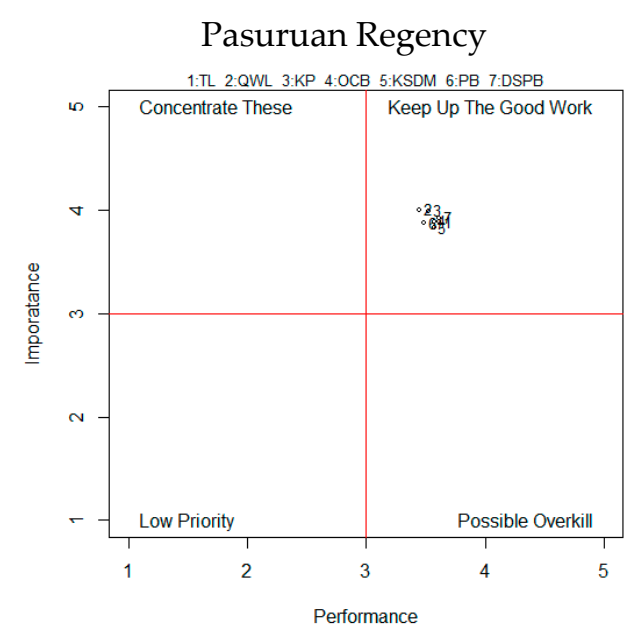

(a)

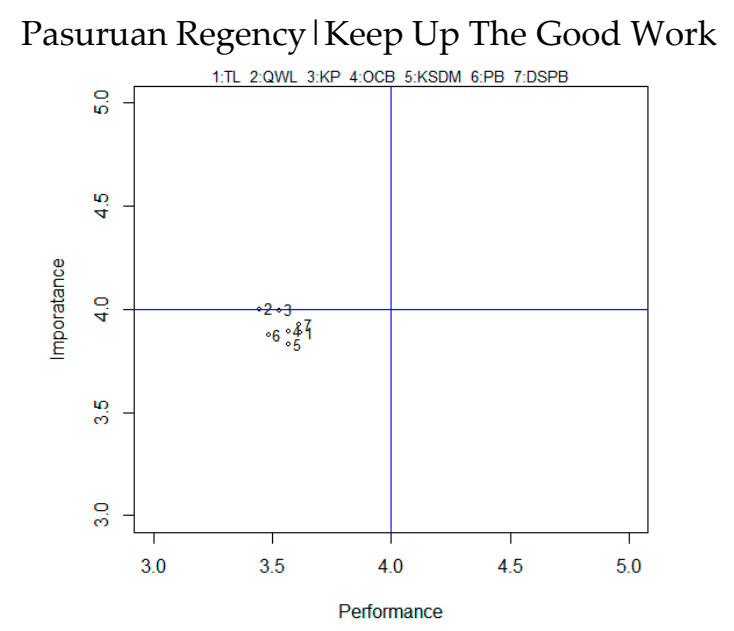

(b)

Figure 5. (a) IPA Cartesian Diagram of Pasuruan Regency. (b) IPA Cartesian Diagram of Keep up the Good Quadrant of Pasuruan Regency.

Based on the Figure A5 in Appendix A, it can be seen that the variable that has the biggest difference between expectations and reality received is the QWL variable, which is 0.55 . Therefore, the main variable that needs to be improved is QWL. Meanwhile, the variable that has the smallest difference between expectations and reality received is the HRP, which is equal to 0.26 . This shows that the HRP received by MSMEs' employees and tourists in Pasuruan Regency is in line with expectations.

\section{(6) Sidoarjo Regency}

The measurement of all variables in Sidoarjo Regency is described in the Cartesian diagram presented in Figure 6, which centers on the TL and HRP axes. Axis TL is the average value of performance level and the HRP axis is the average value of importance. The two axes form two perpendicular lines that intersect each other, dividing the Cartesian diagram into four quadrants.

Based on the Figure A6 in Appendix A, it can be seen that the variable that has the biggest difference between expectations and reality received is the variable STC, which is equal to 0.58 . Hence, the main variable that needs to be improved is STC. Meanwhile, the variable that has the smallest difference between expectations and reality received is the RM variable, which is 0.33 . This shows that RM, which is accepted by MSMEs' employees and tourists in Sidoarjo Regency, is in line with expectations. 


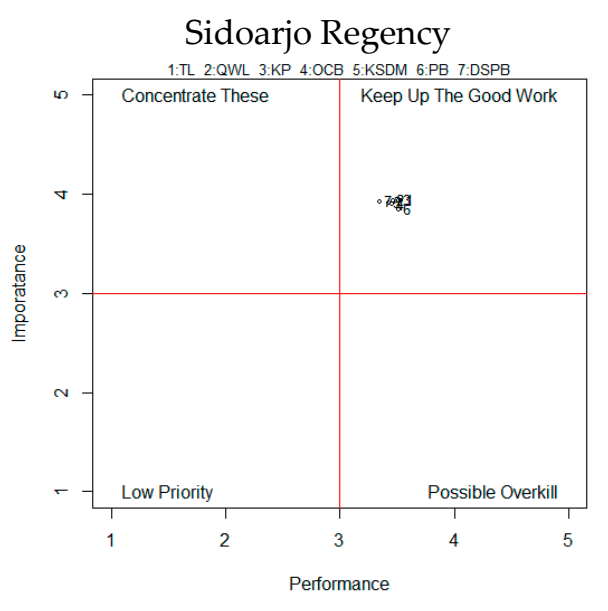

(a)
Sidoarjo Regency IKeep Up The Good Work

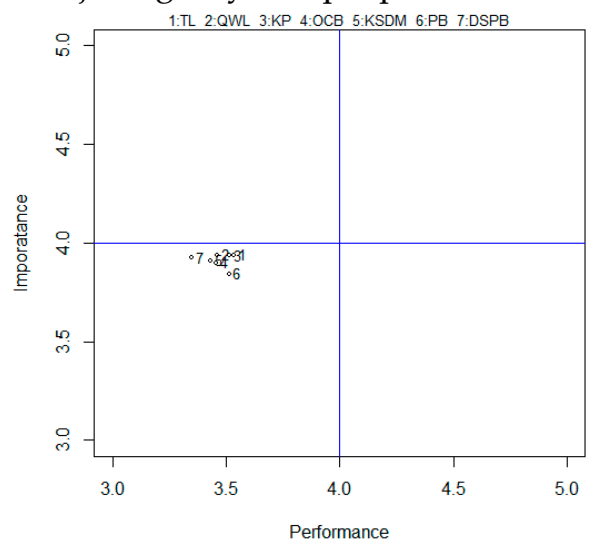

(b)

Figure 6. (a) IPA Cartesian Diagram of Sidoarjo Regency. (b) IPA Cartesian Diagram of Keep up the Good Work Quadrant of Sidoarjo Regency.

\section{(7) Kediri Regency}

The measurement of all variables in Kediri Regency is described in the Cartesian diagram presented in Figure 7, which centers on the TL and HRP axes. Axis TL is the average value of performance level and the HRP axis is the average value of importance. The two axes form two perpendicular lines that intersect each other, dividing the Cartesian diagram into four quadrants.

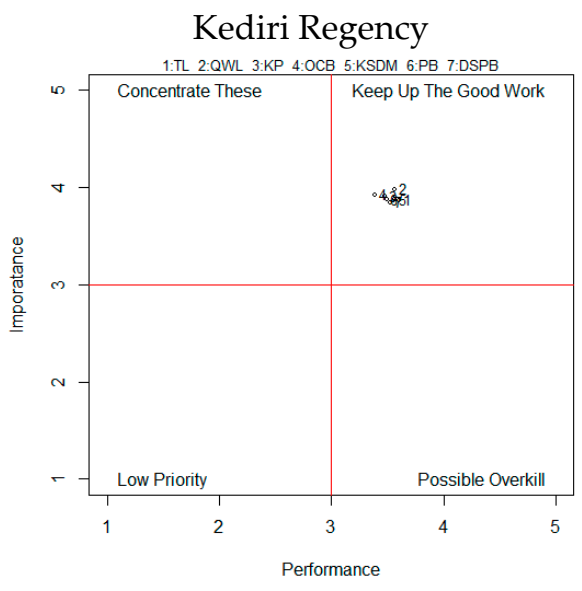

(a)
Kediri Regency |Keep Up The Good Work

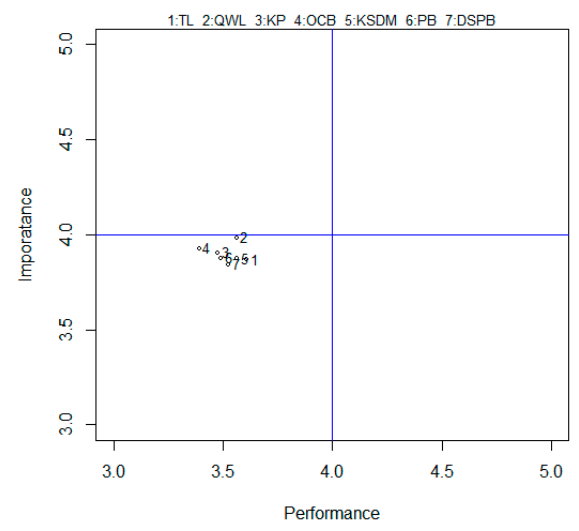

(b)

Figure 7. (a) IPA Cartesian Diagram of Kediri Regency. (b) IPA Cartesian Diagram of Keep up the Good Work Quadrant of Kediri Regency.

The Cartesian diagram above illustrates the expectations (importance) and reality (performance) received by the tourism Sector MSMEs' employees and tourists in Kediri Regency. Based on the diagram, it can be seen that TL, QWL, JI, OCB, HRP, RM and STC are in quadrant II (Keep up the Good Work). This shows that the expectations and reality received by employees and tourists for all variables are equally high. Specifically, the expectation and reality values received by employees and tourists for all variables ranged from 3 to 4 . The difference between expectations and reality received by employees and tourists for each variable is shown in the following bar graph.

Based on the Figure A7 in Appendix A, it can be seen that the variable that has the biggest difference between expectations and reality received is the OCB variable, which is equal to 0.54 . Therefore, the main variable that needs to be corrected is OCB. Meanwhile, the variable that has the smallest 
difference between expectations and reality received is the TL, which is equal to 0.26 . This shows that TL, received by MSMEs' employees and tourists in Kediri Regency is in line with expectations.

\section{(8) Kediri City}

The measurement of all variables in Kediri City is described in the Cartesian diagram presented in Figure 8, which centers on the TL and HRP axes. Axis TL is the average value of performance level and the RHP axis is the average value of importance. The two axes form two perpendicular lines that intersect each other, dividing the Cartesian diagram into four quadrants.

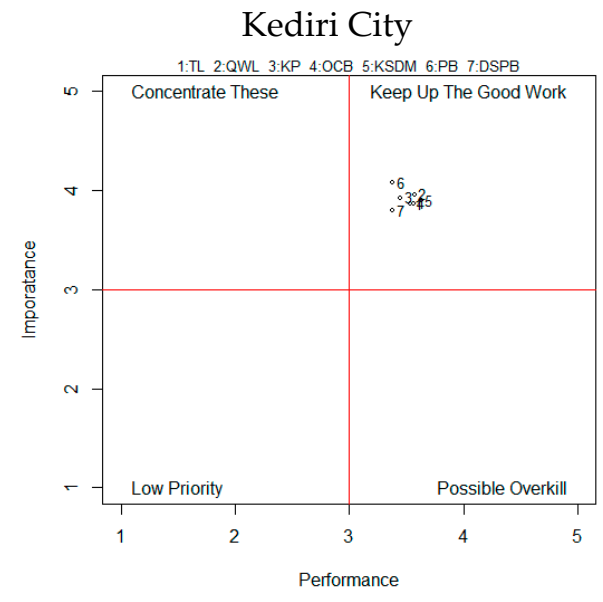

(a)

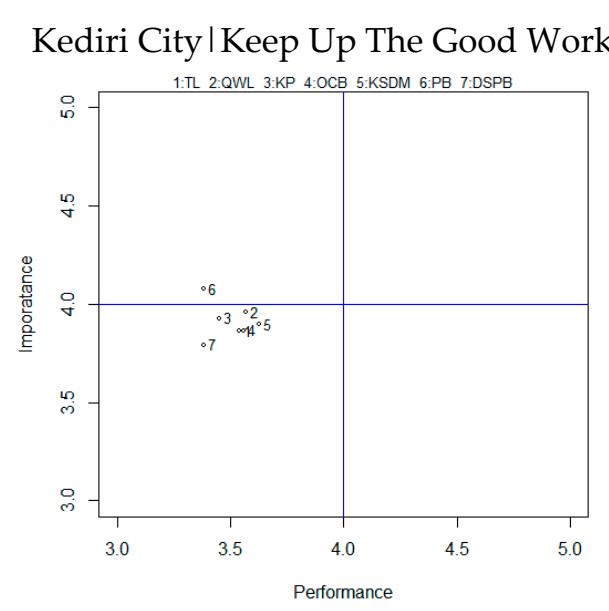

(b)

Figure 8. (a) IPA Cartesian Diagram of Kediri City. (b) IPA Cartesian Diagram of Keep up the Good Work Quadrant of Kediri City.

The Cartesian diagram above illustrates the expectations (importance) and reality (performance) received by the tourism Sector MSMEs' employees and tourists in the Kediri City. Based on the diagram, it can be seen that TL, QWL, JI, OCB, HRP, RM, and STC are in quadrant II (Keep up the Good Work). This shows that the expectations and reality received by employees and tourists for all variables are equally high. Specifically, the expectation and reality values received by employees and tourists for all variables ranged from 3 to 4 . The difference between expectations and reality received by employees and tourists for each variable is shown in the following bar graph.

Based on the Figure A8 in Appendix A, it can be seen that the variable that has the biggest difference between expectations and reality received is the RM, which is equal to 0.69 . Therefore, the main variable that needs to be improved is RM. Meanwhile, the variable that has the smallest difference between expectations and reality received is the HRP, which is 0.27 . This shows that the HRP received by MSMEs' employees and tourists in Kediri City is in line with expectations.

\section{(9) Blitar Regency}

The measurement of all variables in Blitar Regency is described in the Cartesian diagram presented in Figure 9, which centers on the TL and HRP axes. Axis TL is the average value of performance level and the HRP axis is the average value of importance. The two axes form two perpendicular lines that intersect each other, dividing the Cartesian diagram into four quadrants.

The Cartesian diagram above illustrates the expectations (importance) and reality (performance) according to the tourism sector MSMEs' employees and tourists in Blitar Regency. Based on the diagram, it can be seen that TL, QWL, JI, OCB, HRP, RM, and STC are in quadrant II (Keep up the Good Work). This shows that the expectations and reality received by employees and tourists for all variables are equally high. Specifically, the expectation and reality values received by employees and 
tourists for all variables ranged from 3 to 4 . The difference between expectations and reality received by employees and tourists for each variable is shown in the following bar graph.

Based on the Figure A9 in Appendix A, it can be seen that the variable that has the biggest difference between expectations and reality received is the HRP, which is equal to 0.51 . So, the main variable that needs to be improved is HRP. Meanwhile, the variable that has the smallest difference between expectations and reality received is the TL, which is 0.32 . This shows that TL received by MSMEs' employees and tourists in Blitar Regency is in line with expectations.

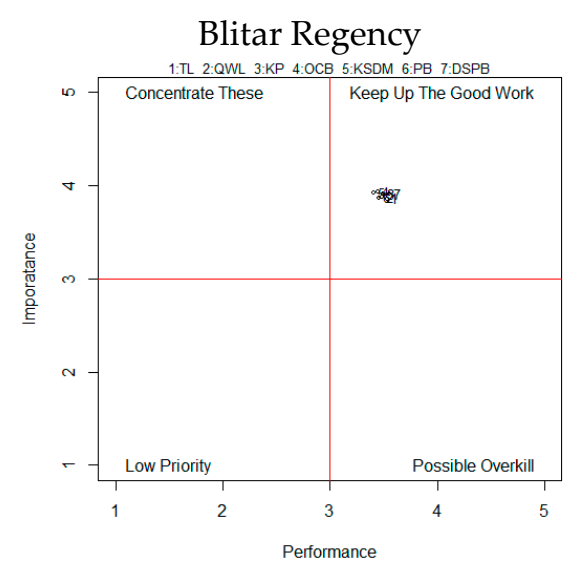

(a)

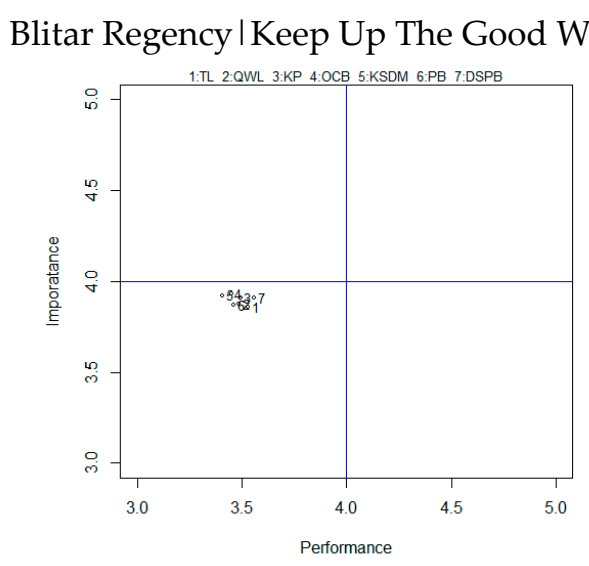

(b)

Figure 9. (a) IPA Cartesian Diagram of Blitar Regency. (b) IPA Cartesian Diagram of Keep up the Good Work Quadrant of Blitar Regency.

\section{(10) Blitar City}

The measurement of all variables in Blitar City is described in the Cartesian diagram presented in Figure 10, which centers on the TL and HRP axes. Axis TL is the average value of performance level and the HRP axis is the average value of importance. The two axes form two perpendicular lines that intersect each other, dividing the Cartesian diagram into four quadrants.

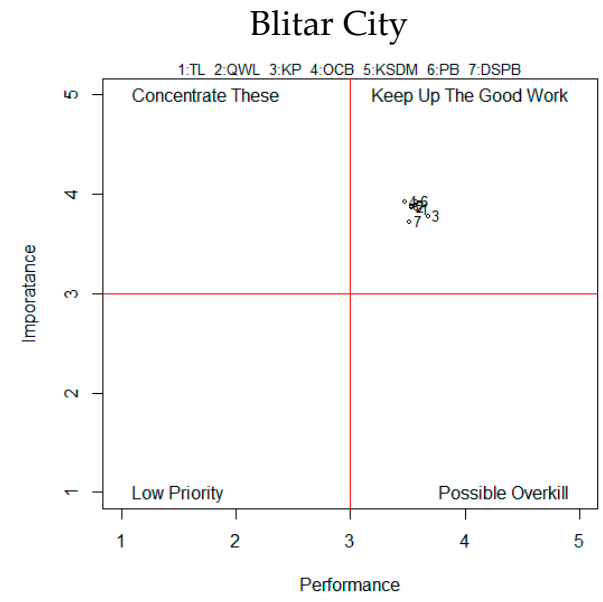

(a)

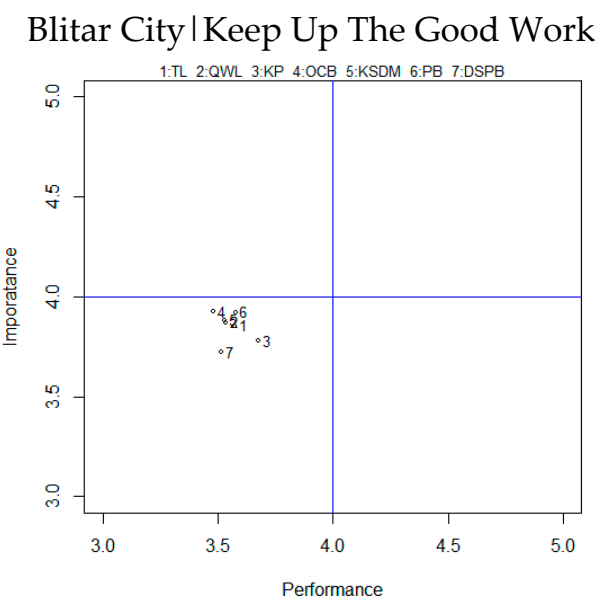

(b)

Figure 10. (a) IPA Cartesian Diagram of Blitar City. (b) IPA Cartesian Diagram of Keep up the Good Work Quadrant of Blitar City.

The Cartesian diagram above illustrates the expectations (importance) and reality (performance) received by the tourism Sector MSMEs' employees and tourists in Blitar City. Based on the diagram, 
it can be seen that TL, QWL, JI, OCB, HRP, RM, and STC are in quadrant II (Keep up the Good Work). This shows that the expectations and reality received by employees and tourists for all variables are equally high. Specifically, the expectation and reality values received by employees and tourists for all variables ranged from 3 to 4 . The difference between expectations and reality received by employees and tourists for each variable is shown in the following bar graph.

Based on the Figure A10 in Appendix A, it can be seen that the variable that has the biggest difference between expectations and reality received is the OCB variable, which is 0.44 . Therefore, the main variable that needs to be corrected is OCB. Meanwhile, the variable that has the smallest difference between expectations and reality received is the EE, which is equal to 0.1 . This shows that WI, which is received by MSMEs' employees and tourists in Blitar City, is in line with expectations.

\section{(11) East Java}

The measurement of all variables in East Java is described in the Cartesian diagram presented in Figure 11, which centers on the TL and HRP axes. Axis TL is the average value of performance level and the HRP axis is the average value of importance. The two axes form two perpendicular lines that intersect each other, dividing the Cartesian diagram into four quadrants.

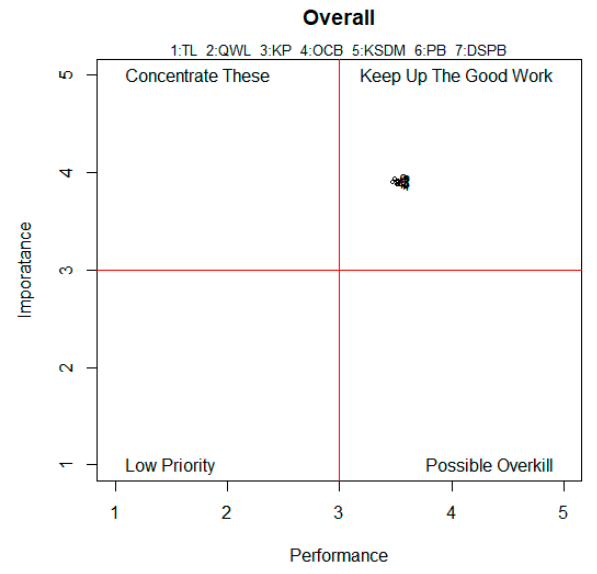

(a)

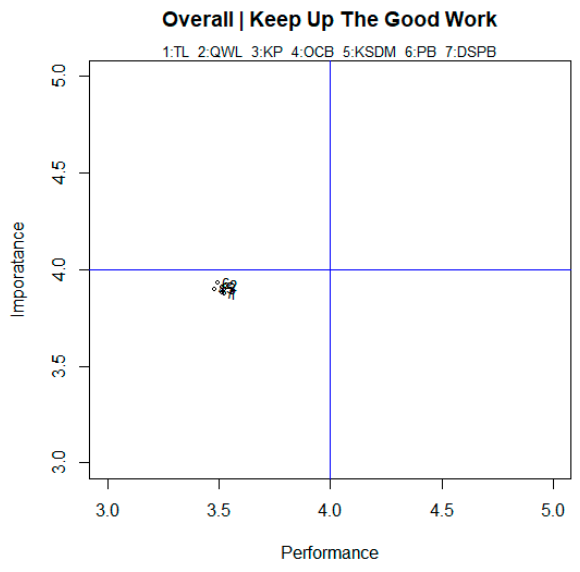

(b)

Figure 11. (a) IPA Cartesian Diagram of Overall. (b) IPA Cartesian Diagram of Keep up the Good Work Quadrant of Overall.

The Cartesian diagram above illustrates the importance (importance) and reality (performance) received by the tourism sector MSMEs' employees and tourists in East Java Province. Based on the diagram, it can be seen that TL, QWL, JI, OCB, HRP, RM, and STC are in quadrant II (Keep up the Good Work). This shows that the expectations and reality received by employees and tourists for all variables are equally high. Specifically, the expectation and reality values received by employees and tourists for all variables ranged from 3 to 4 . The difference between expectations and reality received by employees and tourists for each variable is shown in the following bar graph.

Based on the Figure A11 in Appendix A, it can be seen that the variable that has the biggest difference between expectations and reality received is the RM, which is 0.43 . Therefore, the main variable that needs to be improved is RM. Meanwhile, the variable that has the smallest difference between expectations and reality received is the TL variable, which is equal to 0.1 . This shows that TL, received by MSMEs' employees and tourists in East Java Province, is in line with expectations.

\section{Discussion}

Based on the description of the results of the study discussed earlier, each area of tourism potential in East Java (as a sample) has a gap between expectations (importance) and reality (performance) 
that is different from the variables studied. Certainly, what needs to be considered here is the biggest gap, such that improvements to the variable are needed in order to create balance between expectation (importance) and reality (performance), both for MSMEs' HR and the tourism sector in East Java. For clearer description, the following is results table (see Table 4).

Table 4. Research Result.

\begin{tabular}{ccc}
\hline No & Name of City/Regency & Most Variable Improved \\
\hline 1. & Batu City & TL (Transglobal Leadership) \\
2. & Malang Regency & OCB (Organizational Citizenship Behavior) \\
3. & Malang City & EE (Employee Engagement) \\
4. & Pasuruan City & HRP (Human Resource Performance) \\
5. & Pasuruan Regency & QWL (Quality of Work Life) \\
6. & Sidoarjo Regency & STC (Sustainable Tourism Competitiveness) \\
7. & Kediri Regency & OCB (Organizational Citizenship Behavior) \\
8. & Kediri City & RM (Responsible Marketing) \\
9. & Blitar Regency & HRP (Human Resource Performance) \\
10. & Blitar City & OCB (Organizational Citizenship Behavior) \\
\hline
\end{tabular}

As an example, for Batu City, the main variable that needs to be improved is TL. In Malang Regency, the main variable that needs to be improved is OCB. For Malang City, the main variable that needs to be improved is EE. For Pasuruan City, the main variable that needs to be improved is HRP. Pasuruan Regency, the main variable that needs to be improved is QWL. For Sidoarjo Regency, the main variable that needs to be improved is STC. For Kediri Regency, the main variable that needs to be improved is OCB. Kediri City, the main variable that needs to be improved is RM. For Blitar Regency, the main variable that needs to be improved is HRP. Blitar City, the main variable that needs to be improved is OCB.

Overall, for the East Java region, the main variable that needs to be improved is RM. Therefore, marketing activities must be carried out based on the philosophy of thought of RM. According to [37], the concept of marketing is "the rationale for how marketing activities can be carried out based on a comprehensive philosophy, which reveals responsive and RM." A company in carrying out its activities must run the marketing concept so that the expected benefits can be realized properly. This indicates that marketing activities within the company must be coordinated and managed in an enhanced method. The core concepts of marketing include needs, wants, and demands.

In relation to tourism, responsible tourism marketing is a description of sustainable tourism development in tourism marketing. Sustainable development is vastly relevant in the development of tourism because tourism products are almost always in the form of nature or culture of the community. The tourism sector is very interested in the preservation of natural and cultural resources which are the products that are sold, those which attract tourists from other places to enjoy it.

RM in general is also known as green marketing [38] or [39] environmental marketing. Both concepts are still relevant in the development of responsible tourism marketing. It is only that the principles of sustainable tourism development expand at the same time, influencing the concept of responsible tourism marketing (see Figure 12).

Responsible tourism marketing adds sustainability principles as a variable in marketing decision-making standards. However, this variable is unique and special because it is present wherever and whenever, as a background, when all strategic decision making is carried out [40]. All decisions in tourism marketing, such as product development, promotion, and marketing efforts to attract and win tourist loyalty must incorporate these principles. Implementation of a RM strategy has two objectives [41], namely: (1) developing products that balance the needs of costumers (in this case tourists) for quality, affordable prices, and comfort with the protection of environmental, social, and cultural resources, and (2) creating a high-quality image, which also includes sensitivity to the 
environment and a track record of environmental maintenance for tourism products developed by a destination.

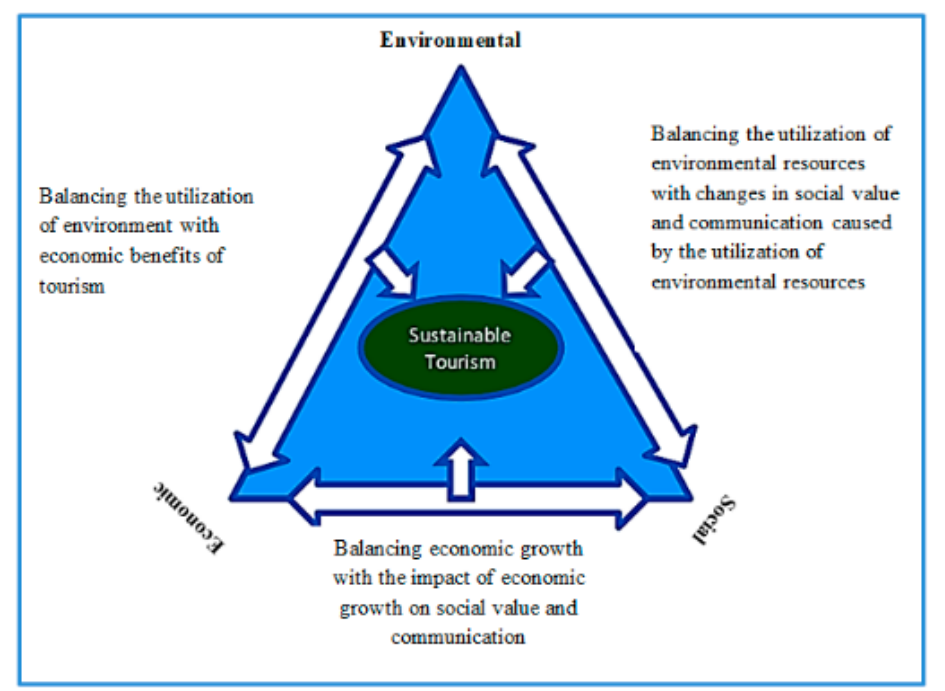

Figure 12. Sustainable Tourism achieved through Balancing Environmental, Economic and Social Aspects. [36].

\section{Conclusions}

The modern economy can be modeled as entrepreneurial cyclical dynamics of open innovation with three sub-economies. There is market open innovation by SMEs and start-ups, closed open innovation by big business, and social open innovation [42]. A certain country is included in which one of three sub-economies will depend on the quality of human capital. It is in line with [43] that human capital success emphasizes the capabilities of individuals. People with good skills, intelligence, and creativity are more likely to innovate. In line with this, [44] stated that when companies develop new products or services, it is essential to foster organizational innovativeness, and managing human resource is a key to this. Human resource (HR) practices are essential tools by which companies can shape the skills, attitudes, and behaviour of individuals to do their work and can systematise the work of the whole organization. Moreover, innovation also support the sustainability of organization life. Ref. [45] stated that sustainability can be achieved through open innovation in the current 4th industrial revolution. Thus, an organization should develop conducive environment to innovate. Culture, in its various forms, has always been a critical driver of innovation [46].

The aim of the research paper is to get a depiction of the level of satisfaction and importance of MSMEs' HR and the tourism sector community in East Java. The research was conducted on all aspects of HR in tourism sector MSMEs, among foreign and domestic tourists in East Java. IPA was utilized as an analysis tool in this paper.

Based on analysis conducted, it is known that RM is the main thing that needs to be improved in tourism marketing in East Java. In relation to tourism, responsible tourism marketing is a description of sustainable tourism development in tourism marketing. Sustainable development is vastly relevant in the development of tourism because tourism products are almost always in the form of nature or the culture of the community. The tourism sector is very interested in the preservation of natural and cultural resources, which are the products that are sold which attract tourists from other places to enjoy it.

The research findings provide a practical contribution to the stakeholders of the tourism sector, especially to those responsible for improving its performance. In this case, culture and tourism offices can follow up the findings with relevant policies. The research has many limitations, including: the scope of the research is limited to East Java. So, the generalization of the research findings will be 
problematic. Future research can broaden the scope of existing research to overcome the problem of generalizability of the research findings.

Author Contributions: Conceptualization, A.H.; Formal analysis, A.H.; Funding acquisition, A.H.; Investigation, N.N. and S.S.; Methodology, N.N.; Project administration, S.S.; Resources, S.S.; Software, Z.M.; Supervision Z.M.; Validation, S.S. and S.A.; Visualization, S.A.; Writing—original draft, Z.M.; Writing—review \& editing, S.A. All authors have read and agreed to the published version of the manuscript.

Funding: This research received no external funding.

Conflicts of Interest: The authors declare no conflict of interest.

\section{Abbreviations}

Human Resources $\quad$ (HR)

Importance Performance Analysis (IPA)

Transglobal Leadership (TL)

Organizational Citizenship Behavior (OCB)

Employment Engagement (EE)

Human Resources Performance (HRP)

Quality of Work Life (QWL)

Sustainable Tourism Competitiveness (STC)

Responsible Marketing (RM)

Gross Regional Domestic Product (GRDP)

Job Involvement (JI)

Work Engagement (WE)

\section{Appendix A}

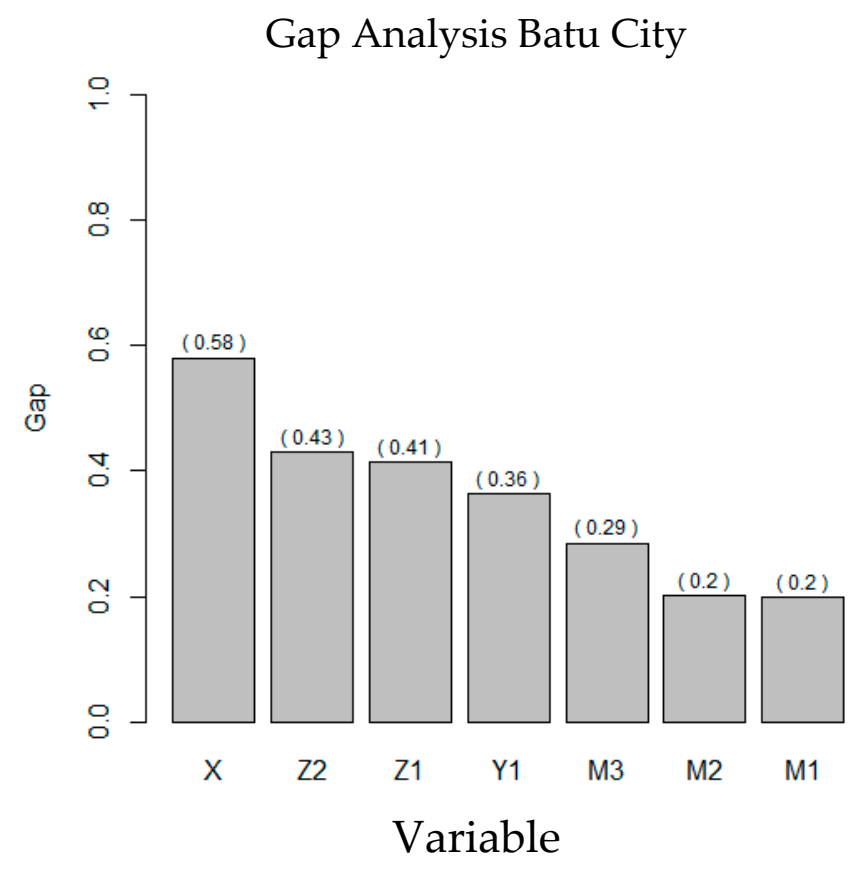

Figure A1. Bar Diagram of Gap Analysis of Batu City. 


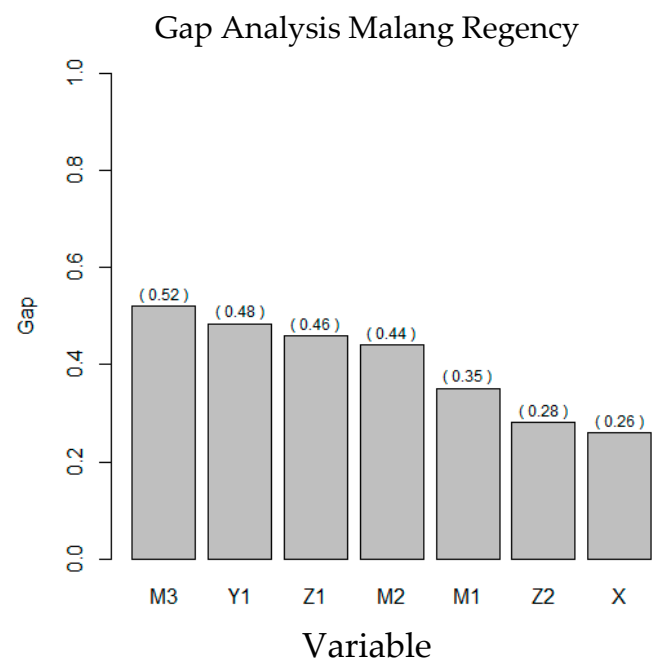

Figure A2. Bar Diagram of Gap Analysis of Malang Regency.

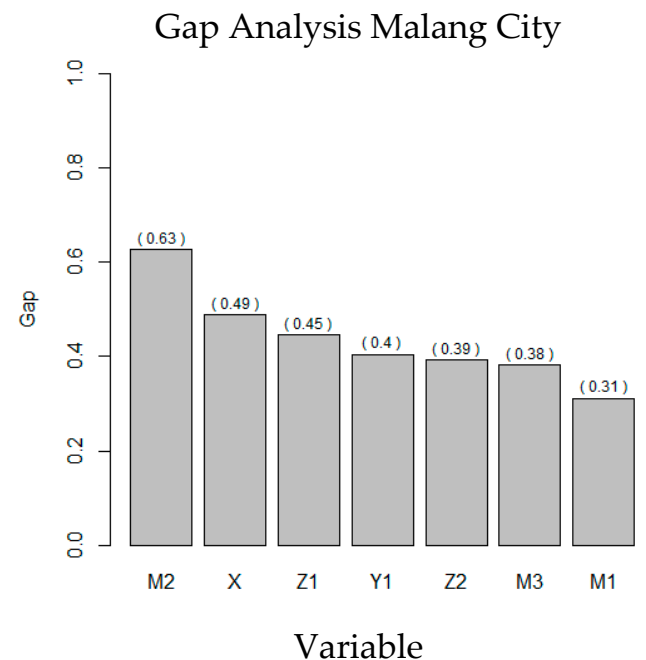

Figure A3. Bar Diagram of Gap Analysis of Malang City.

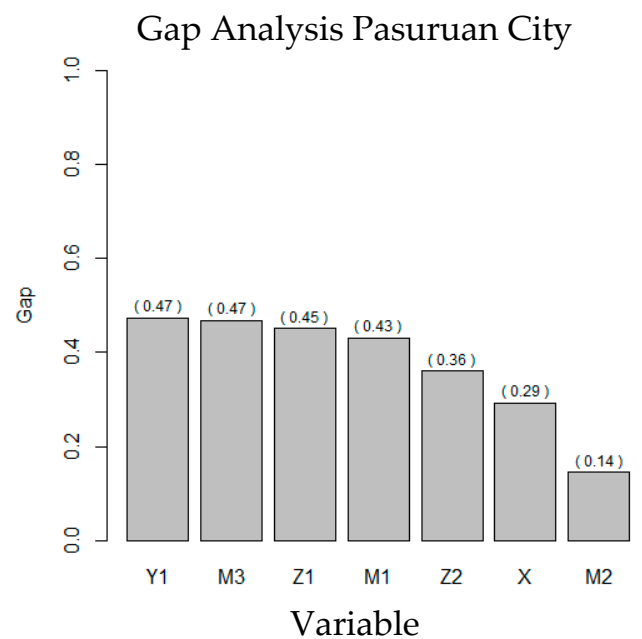

Figure A4. Bar Diagram of Gap Analysis of Pasuruan City. 


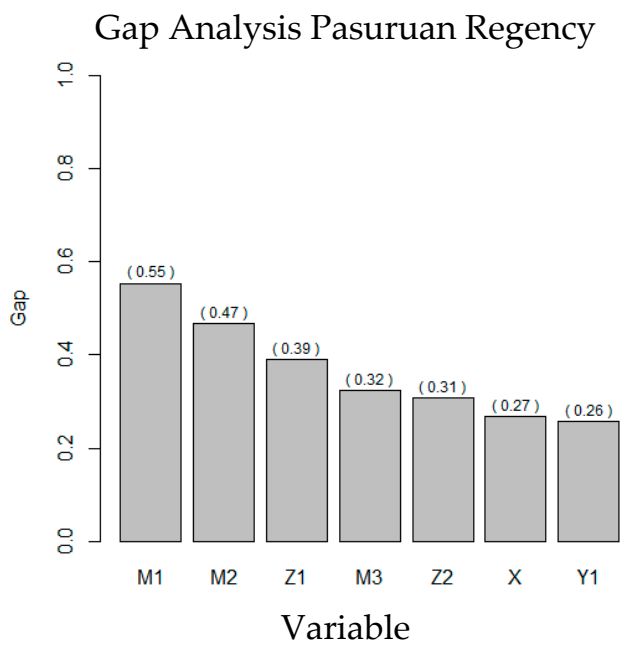

Figure A5. Bar Diagram of Gap Analysis of Pasuruan Regency.

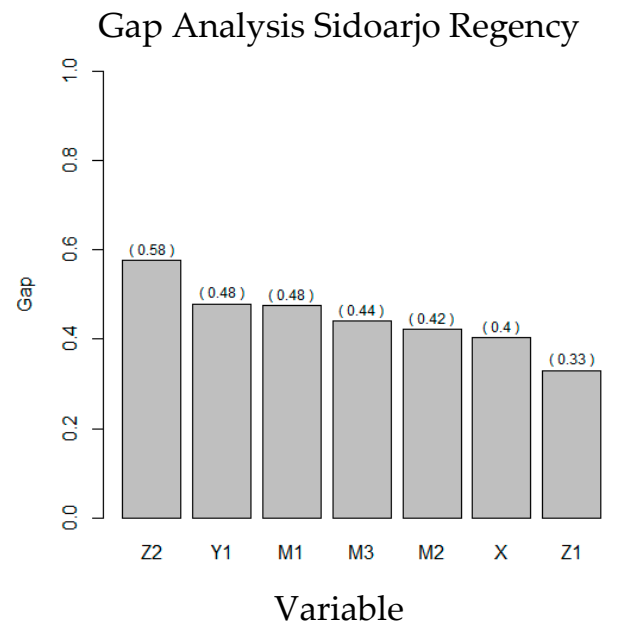

Figure A6. Bar Diagram of Gap Analysis of Sidoarjo Regency.

Gap Analysis Kediri Regency

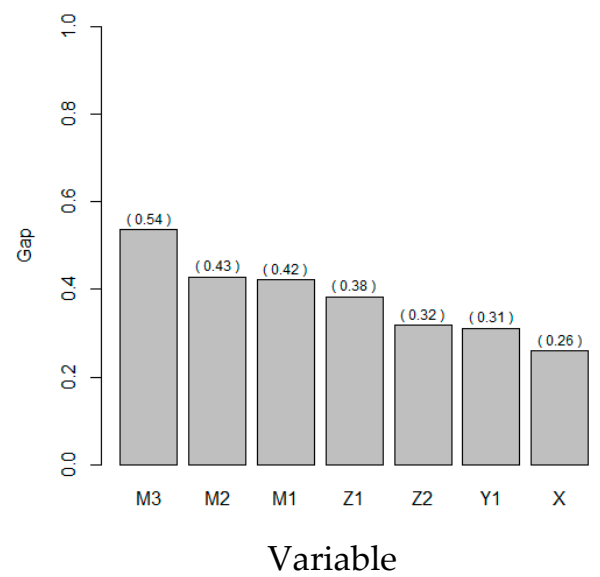

Figure A7. Bar Diagram of Gap Analysis of Kediri Regency. 


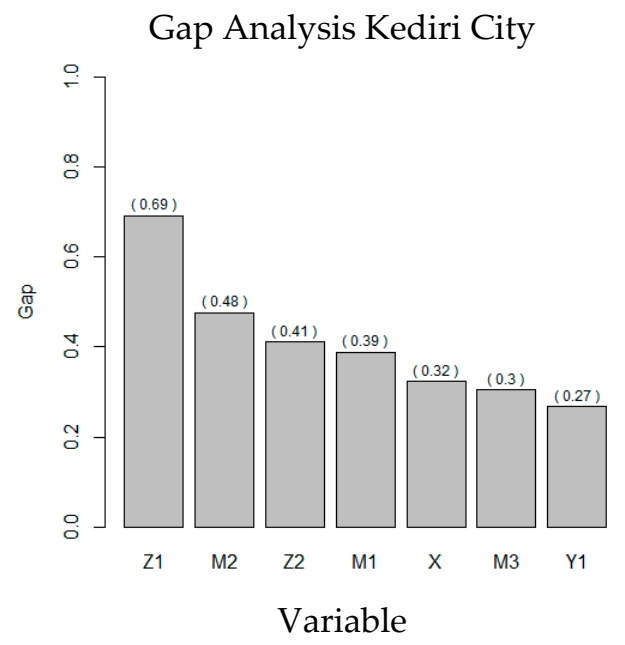

Figure A8. Bar Diagram of Gap Analysis of Kediri City.

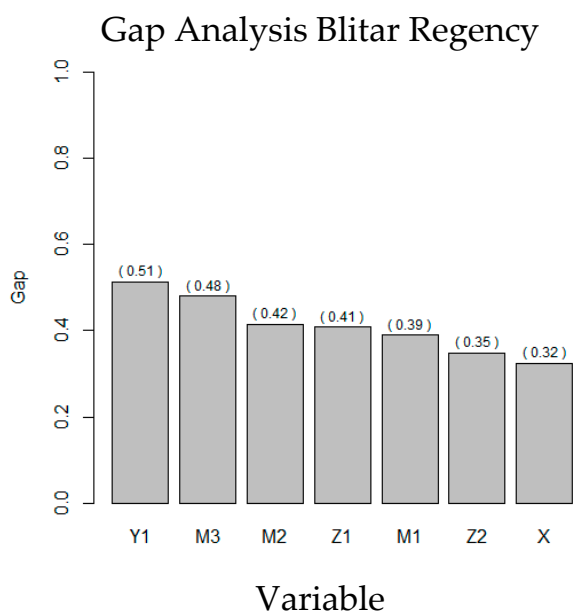

Figure A9. Bar Diagram of Gap Analysis of Blitar Regency.

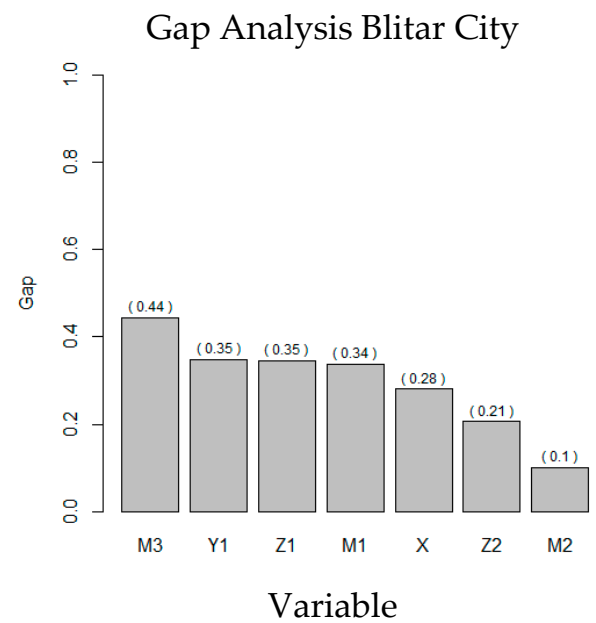

Figure A10. Bar Diagram of Gap Analysis of Blitar city. 


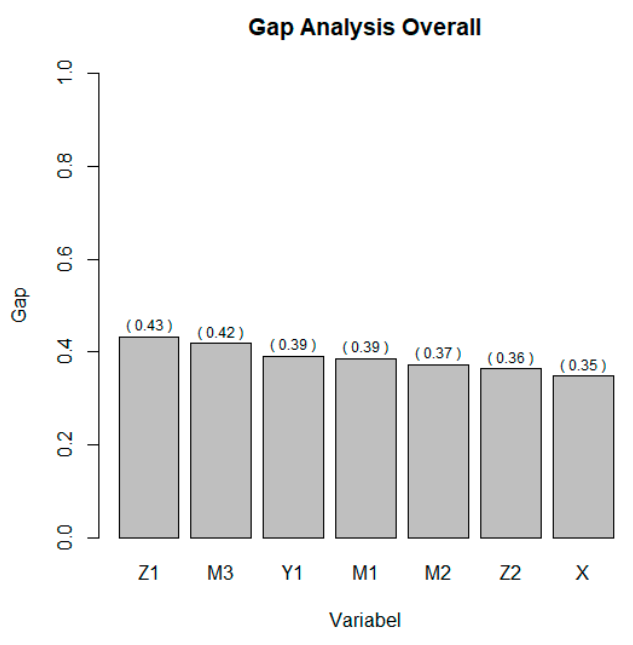

Figure A11. Bar Diagram of Gap Analysis of Overall.

\section{Appendix A.1. Questionnaire}

1. In order to improve the performance of SMEs in the tourism sector, the criteria required are:
A. Transglobal leadership
B. Quality of Work Life (QWL)
C. Job Involvement
D. Employee performance

Please mark a cross $(X)$ on the weight scale you want/feel

\begin{tabular}{|l|l|l|l|l|l|l|l|l|l|l|l|l|l|l|l|l|l|l|l|}
\hline 1 & $\mathrm{~A}$ & 9 & 8 & 7 & 6 & 5 & 4 & 3 & 2 & 1 & 2 & 3 & 4 & 5 & 6 & 7 & 8 & 9 & $\mathrm{~B}$ \\
\hline 2 & $\mathrm{~A}$ & 9 & 8 & 7 & 6 & 5 & 4 & 3 & 2 & 1 & 2 & 3 & 4 & 5 & 6 & 7 & 8 & 9 & $\mathrm{C}$ \\
\hline 3 & $\mathrm{~A}$ & 9 & 8 & 7 & 6 & 5 & 4 & 3 & 2 & 1 & 2 & 3 & 4 & 5 & 6 & 7 & 8 & 9 & $\mathrm{D}$ \\
\hline 4 & $\mathrm{~B}$ & 9 & 8 & 7 & 6 & 5 & 4 & 3 & 2 & 1 & 2 & 3 & 4 & 5 & 6 & 7 & 8 & 9 & $\mathrm{C}$ \\
\hline 5 & $\mathrm{~B}$ & 9 & 8 & 7 & 6 & 5 & 4 & 3 & 2 & 1 & 2 & 3 & 4 & 5 & 6 & 7 & 8 & 9 & $\mathrm{D}$ \\
\hline 6 & $\mathrm{C}$ & 9 & 8 & 7 & 6 & 5 & 4 & 3 & 2 & 1 & 2 & 3 & 4 & 5 & 6 & 7 & 8 & 9 & $\mathrm{D}$ \\
\hline
\end{tabular}

2. The actors who play a role in transglobal leadership are:
A. Public
B. Head of SMEs
C. Employees
D. Relevant agencies

Please mark a cross $(X)$ on the weight scale you want/feel

\begin{tabular}{|l|l|l|l|l|l|l|l|l|l|l|l|l|l|l|l|l|l|l|l|}
\hline 1 & $\mathrm{~A}$ & 9 & 8 & 7 & 6 & 5 & 4 & 3 & 2 & 1 & 2 & 3 & 4 & 5 & 6 & 7 & 8 & 9 & $\mathrm{~B}$ \\
\hline 2 & $\mathrm{~A}$ & 9 & 8 & 7 & 6 & 5 & 4 & 3 & 2 & 1 & 2 & 3 & 4 & 5 & 6 & 7 & 8 & 9 & $\mathrm{C}$ \\
\hline 3 & $\mathrm{~A}$ & 9 & 8 & 7 & 6 & 5 & 4 & 3 & 2 & 1 & 2 & 3 & 4 & 5 & 6 & 7 & 8 & 9 & $\mathrm{D}$ \\
\hline 4 & $\mathrm{~B}$ & 9 & 8 & 7 & 6 & 5 & 4 & 3 & 2 & 1 & 2 & 3 & 4 & 5 & 6 & 7 & 8 & 9 & $\mathrm{C}$ \\
\hline 5 & $\mathrm{~B}$ & 9 & 8 & 7 & 6 & 5 & 4 & 3 & 2 & 1 & 2 & 3 & 4 & 5 & 6 & 7 & 8 & 9 & $\mathrm{D}$ \\
\hline 6 & $\mathrm{C}$ & 9 & 8 & 7 & 6 & 5 & 4 & 3 & 2 & 1 & 2 & 3 & 4 & 5 & 6 & 7 & 8 & 9 & $\mathrm{D}$ \\
\hline
\end{tabular}

3. The actors who play a role in ensuring the Quality of Work Life (QWL) are:
A. Public
B. Head of SMEs
C. Employees
D. Relevant agencies

Please mark a cross $(\mathrm{X})$ on the weight scale you want/feel 


\begin{tabular}{|c|c|c|c|c|c|c|c|c|c|c|c|c|c|c|c|c|c|c|c|}
\hline 1 & $\mathrm{~A}$ & 9 & 8 & 7 & 6 & 5 & 4 & 3 & 2 & 1 & 2 & 3 & 4 & 5 & 6 & 7 & 8 & 9 & $\mathrm{~B}$ \\
\hline 2 & $\mathrm{~A}$ & 9 & 8 & 7 & 6 & 5 & 4 & 3 & 2 & 1 & 2 & 3 & 4 & 5 & 6 & 7 & 8 & 9 & $\mathrm{C}$ \\
\hline 3 & $\mathrm{~A}$ & 9 & 8 & 7 & 6 & 5 & 4 & 3 & 2 & 1 & 2 & 3 & 4 & 5 & 6 & 7 & 8 & 9 & $\mathrm{D}$ \\
\hline 4 & $\mathrm{~B}$ & 9 & 8 & 7 & 6 & 5 & 4 & 3 & 2 & 1 & 2 & 3 & 4 & 5 & 6 & 7 & 8 & 9 & $\mathrm{C}$ \\
\hline 5 & $\mathrm{~B}$ & 9 & 8 & 7 & 6 & 5 & 4 & 3 & 2 & 1 & 2 & 3 & 4 & 5 & 6 & 7 & 8 & 9 & $\mathrm{D}$ \\
\hline 6 & $\mathrm{C}$ & 9 & 8 & 7 & 6 & 5 & 4 & 3 & 2 & 1 & 2 & 3 & 4 & 5 & 6 & 7 & 8 & 9 & $\mathrm{D}$ \\
\hline
\end{tabular}

4. Actors who play a role in ensuring Job Involvement are:
A. Public
B. Head of SMEs
C. Employees
D. Relevant agencies

Please mark a cross $(X)$ on the weight scale you want/feel

\begin{tabular}{|l|l|l|l|l|l|l|l|l|l|l|l|l|l|l|l|l|l|l|l|}
\hline 1 & $\mathrm{~A}$ & 9 & 8 & 7 & 6 & 5 & 4 & 3 & 2 & 1 & 2 & 3 & 4 & 5 & 6 & 7 & 8 & 9 & $\mathrm{~B}$ \\
\hline 2 & $\mathrm{~A}$ & 9 & 8 & 7 & 6 & 5 & 4 & 3 & 2 & 1 & 2 & 3 & 4 & 5 & 6 & 7 & 8 & 9 & $\mathrm{C}$ \\
\hline 3 & $\mathrm{~A}$ & 9 & 8 & 7 & 6 & 5 & 4 & 3 & 2 & 1 & 2 & 3 & 4 & 5 & 6 & 7 & 8 & 9 & $\mathrm{D}$ \\
\hline 4 & $\mathrm{~B}$ & 9 & 8 & 7 & 6 & 5 & 4 & 3 & 2 & 1 & 2 & 3 & 4 & 5 & 6 & 7 & 8 & 9 & $\mathrm{C}$ \\
\hline 5 & $\mathrm{~B}$ & 9 & 8 & 7 & 6 & 5 & 4 & 3 & 2 & 1 & 2 & 3 & 4 & 5 & 6 & 7 & 8 & 9 & $\mathrm{D}$ \\
\hline 6 & $\mathrm{C}$ & 9 & 8 & 7 & 6 & 5 & 4 & 3 & 2 & 1 & 2 & 3 & 4 & 5 & 6 & 7 & 8 & 9 & $\mathrm{D}$ \\
\hline
\end{tabular}

5. The actors who play a role in ensuring employee performance are:
A. Public
B. Head of SMEs
C. Employees
D. Relevant agencies

Please mark a cross $(X)$ on the weight scale you want/feel

\begin{tabular}{|l|l|l|l|l|l|l|l|l|l|l|l|l|l|l|l|l|l|l|l|l|}
\hline 1 & A & 9 & 8 & 7 & 6 & 5 & 4 & 3 & 2 & 1 & 2 & 3 & 4 & 5 & 6 & 7 & 8 & 9 & B \\
\hline 2 & A & 9 & 8 & 7 & 6 & 5 & 4 & 3 & 2 & 1 & 2 & 3 & 4 & 5 & 6 & 7 & 8 & 9 & $\mathrm{C}$ \\
\hline 3 & A & 9 & 8 & 7 & 6 & 5 & 4 & 3 & 2 & 1 & 2 & 3 & 4 & 5 & 6 & 7 & 8 & 9 & $\mathrm{D}$ \\
\hline 4 & B & 9 & 8 & 7 & 6 & 5 & 4 & 3 & 2 & 1 & 2 & 3 & 4 & 5 & 6 & 7 & 8 & 9 & $\mathrm{C}$ \\
\hline 5 & B & 9 & 8 & 7 & 6 & 5 & 4 & 3 & 2 & 1 & 2 & 3 & 4 & 5 & 6 & 7 & 8 & 9 & $\mathrm{D}$ \\
\hline 6 & $\mathrm{C}$ & 9 & 8 & 7 & 6 & 5 & 4 & 3 & 2 & 1 & 2 & 3 & 4 & 5 & 6 & 7 & 8 & 9 & $\mathrm{D}$ \\
\hline
\end{tabular}

6. The role of the community in achieving the goals of SMEs performance is:
A. Increase Professionalism
B. Increase Productivity
C. Improve Service Quality
D. Improve SMEs Image

Please mark a cross $(X)$ on the weight scale you want/feel

\begin{tabular}{|l|l|l|l|l|l|l|l|l|l|l|l|l|l|l|l|l|l|l|l|}
\hline 1 & $\mathrm{~A}$ & 9 & 8 & 7 & 6 & 5 & 4 & 3 & 2 & 1 & 2 & 3 & 4 & 5 & 6 & 7 & 8 & 9 & $\mathrm{~B}$ \\
\hline 2 & $\mathrm{~A}$ & 9 & 8 & 7 & 6 & 5 & 4 & 3 & 2 & 1 & 2 & 3 & 4 & 5 & 6 & 7 & 8 & 9 & $\mathrm{C}$ \\
\hline 3 & $\mathrm{~A}$ & 9 & 8 & 7 & 6 & 5 & 4 & 3 & 2 & 1 & 2 & 3 & 4 & 5 & 6 & 7 & 8 & 9 & $\mathrm{D}$ \\
\hline 4 & $\mathrm{~B}$ & 9 & 8 & 7 & 6 & 5 & 4 & 3 & 2 & 1 & 2 & 3 & 4 & 5 & 6 & 7 & 8 & 9 & $\mathrm{C}$ \\
\hline 5 & $\mathrm{~B}$ & 9 & 8 & 7 & 6 & 5 & 4 & 3 & 2 & 1 & 2 & 3 & 4 & 5 & 6 & 7 & 8 & 9 & $\mathrm{D}$ \\
\hline 6 & $\mathrm{C}$ & 9 & 8 & 7 & 6 & 5 & 4 & 3 & 2 & 1 & 2 & 3 & 4 & 5 & 6 & 7 & 8 & 9 & $\mathrm{D}$ \\
\hline
\end{tabular}

7. The role of the Head in achieving the performance goals of SMEs are:
A. Increase Professionalism
B. Increase Productivity
C. Improve Service Quality
D. Improve SMEs Image 
Please mark a cross $(X)$ on the weight scale you want/feel

\begin{tabular}{|l|l|l|l|l|l|l|l|l|l|l|l|l|l|l|l|l|l|l|l|}
\hline 1 & $\mathrm{~A}$ & 9 & 8 & 7 & 6 & 5 & 4 & 3 & 2 & 1 & 2 & 3 & 4 & 5 & 6 & 7 & 8 & 9 & $\mathrm{~B}$ \\
\hline 2 & $\mathrm{~A}$ & 9 & 8 & 7 & 6 & 5 & 4 & 3 & 2 & 1 & 2 & 3 & 4 & 5 & 6 & 7 & 8 & 9 & $\mathrm{C}$ \\
\hline 3 & $\mathrm{~A}$ & 9 & 8 & 7 & 6 & 5 & 4 & 3 & 2 & 1 & 2 & 3 & 4 & 5 & 6 & 7 & 8 & 9 & $\mathrm{D}$ \\
\hline 4 & $\mathrm{~B}$ & 9 & 8 & 7 & 6 & 5 & 4 & 3 & 2 & 1 & 2 & 3 & 4 & 5 & 6 & 7 & 8 & 9 & $\mathrm{C}$ \\
\hline 5 & $\mathrm{~B}$ & 9 & 8 & 7 & 6 & 5 & 4 & 3 & 2 & 1 & 2 & 3 & 4 & 5 & 6 & 7 & 8 & 9 & $\mathrm{D}$ \\
\hline 6 & $\mathrm{C}$ & 9 & 8 & 7 & 6 & 5 & 4 & 3 & 2 & 1 & 2 & 3 & 4 & 5 & 6 & 7 & 8 & 9 & $\mathrm{D}$ \\
\hline
\end{tabular}

8. The role of employees in achieving SMEs performance goals is:
A. Increase Professionalism
B. Increase Productivity
C. Improve Service Quality
D. Improve SMEs Image

Please mark a cross $(X)$ on the weight scale you want/feel

\begin{tabular}{|l|l|l|l|l|l|l|l|l|l|l|l|l|l|l|l|l|l|l|l|}
\hline 1 & $\mathrm{~A}$ & 9 & 8 & 7 & 6 & 5 & 4 & 3 & 2 & 1 & 2 & 3 & 4 & 5 & 6 & 7 & 8 & 9 & $\mathrm{~B}$ \\
\hline 2 & $\mathrm{~A}$ & 9 & 8 & 7 & 6 & 5 & 4 & 3 & 2 & 1 & 2 & 3 & 4 & 5 & 6 & 7 & 8 & 9 & $\mathrm{C}$ \\
\hline 3 & $\mathrm{~A}$ & 9 & 8 & 7 & 6 & 5 & 4 & 3 & 2 & 1 & 2 & 3 & 4 & 5 & 6 & 7 & 8 & 9 & $\mathrm{D}$ \\
\hline 4 & $\mathrm{~B}$ & 9 & 8 & 7 & 6 & 5 & 4 & 3 & 2 & 1 & 2 & 3 & 4 & 5 & 6 & 7 & 8 & 9 & $\mathrm{C}$ \\
\hline 5 & $\mathrm{~B}$ & 9 & 8 & 7 & 6 & 5 & 4 & 3 & 2 & 1 & 2 & 3 & 4 & 5 & 6 & 7 & 8 & 9 & $\mathrm{D}$ \\
\hline 6 & $\mathrm{C}$ & 9 & 8 & 7 & 6 & 5 & 4 & 3 & 2 & 1 & 2 & 3 & 4 & 5 & 6 & 7 & 8 & 9 & $\mathrm{D}$ \\
\hline
\end{tabular}

9. The roles of related agencies in achieving the goals of SMEs performance are:
A. Increase Professionalism
B. Increase Productivity
C. Improve Service Quality
D. Improve SMEs Image

Please mark a cross $(X)$ on the weight scale you want/feel

\begin{tabular}{|c|c|c|c|c|c|c|c|c|c|c|c|c|c|c|c|c|c|c|c|}
\hline 1 & $\mathrm{~A}$ & 9 & 8 & 7 & 6 & 5 & 4 & 3 & 2 & 1 & 2 & 3 & 4 & 5 & 6 & 7 & 8 & 9 & $\mathrm{~B}$ \\
\hline 2 & $\mathrm{~A}$ & 9 & 8 & 7 & 6 & 5 & 4 & 3 & 2 & 1 & 2 & 3 & 4 & 5 & 6 & 7 & 8 & 9 & $\mathrm{C}$ \\
\hline 3 & $\mathrm{~A}$ & 9 & 8 & 7 & 6 & 5 & 4 & 3 & 2 & 1 & 2 & 3 & 4 & 5 & 6 & 7 & 8 & 9 & $\mathrm{D}$ \\
\hline 4 & $\mathrm{~B}$ & 9 & 8 & 7 & 6 & 5 & 4 & 3 & 2 & 1 & 2 & 3 & 4 & 5 & 6 & 7 & 8 & 9 & $\mathrm{C}$ \\
\hline 5 & $\mathrm{~B}$ & 9 & 8 & 7 & 6 & 5 & 4 & 3 & 2 & 1 & 2 & 3 & 4 & 5 & 6 & 7 & 8 & 9 & $\mathrm{D}$ \\
\hline 6 & $\mathrm{C}$ & 9 & 8 & 7 & 6 & 5 & 4 & 3 & 2 & 1 & 2 & 3 & 4 & 5 & 6 & 7 & 8 & 9 & $\mathrm{D}$ \\
\hline
\end{tabular}

10. The strategic priorities used in improving the professionalism of SMEs are:
A. Global Intelligence
B. Work environment
C. Performance self-esteem contingency
D. Behavior of Work

Please mark a cross $(X)$ on the weight scale you want/feel

\begin{tabular}{|l|l|l|l|l|l|l|l|l|l|l|l|l|l|l|l|l|l|l|l|}
\hline 1 & $\mathrm{~A}$ & 9 & 8 & 7 & 6 & 5 & 4 & 3 & 2 & 1 & 2 & 3 & 4 & 5 & 6 & 7 & 8 & 9 & $\mathrm{~B}$ \\
\hline 2 & $\mathrm{~A}$ & 9 & 8 & 7 & 6 & 5 & 4 & 3 & 2 & 1 & 2 & 3 & 4 & 5 & 6 & 7 & 8 & 9 & $\mathrm{C}$ \\
\hline 3 & $\mathrm{~A}$ & 9 & 8 & 7 & 6 & 5 & 4 & 3 & 2 & 1 & 2 & 3 & 4 & 5 & 6 & 7 & 8 & 9 & $\mathrm{D}$ \\
\hline 4 & $\mathrm{~B}$ & 9 & 8 & 7 & 6 & 5 & 4 & 3 & 2 & 1 & 2 & 3 & 4 & 5 & 6 & 7 & 8 & 9 & $\mathrm{C}$ \\
\hline 5 & $\mathrm{~B}$ & 9 & 8 & 7 & 6 & 5 & 4 & 3 & 2 & 1 & 2 & 3 & 4 & 5 & 6 & 7 & 8 & 9 & $\mathrm{D}$ \\
\hline 6 & $\mathrm{C}$ & 9 & 8 & 7 & 6 & 5 & 4 & 3 & 2 & 1 & 2 & 3 & 4 & 5 & 6 & 7 & 8 & 9 & $\mathrm{D}$ \\
\hline
\end{tabular}

11. The strategic priorities used in increasing the productivity of SMEs are:
A. Global Intelligence
B. Work environment
C. Performance self-esteem contingency
D. Behavior of Work 
Please mark a cross $(\mathrm{X})$ on the weight scale you want/feel

\begin{tabular}{|c|c|c|c|c|c|c|c|c|c|c|c|c|c|c|c|c|c|c|c|}
\hline 1 & $\mathrm{~A}$ & 9 & 8 & 7 & 6 & 5 & 4 & 3 & 2 & 1 & 2 & 3 & 4 & 5 & 6 & 7 & 8 & 9 & $\mathrm{~B}$ \\
\hline 2 & $\mathrm{~A}$ & 9 & 8 & 7 & 6 & 5 & 4 & 3 & 2 & 1 & 2 & 3 & 4 & 5 & 6 & 7 & 8 & 9 & $\mathrm{C}$ \\
\hline 3 & $\mathrm{~A}$ & 9 & 8 & 7 & 6 & 5 & 4 & 3 & 2 & 1 & 2 & 3 & 4 & 5 & 6 & 7 & 8 & 9 & $\mathrm{D}$ \\
\hline 4 & $\mathrm{~B}$ & 9 & 8 & 7 & 6 & 5 & 4 & 3 & 2 & 1 & 2 & 3 & 4 & 5 & 6 & 7 & 8 & 9 & $\mathrm{C}$ \\
\hline 5 & $\mathrm{~B}$ & 9 & 8 & 7 & 6 & 5 & 4 & 3 & 2 & 1 & 2 & 3 & 4 & 5 & 6 & 7 & 8 & 9 & $\mathrm{D}$ \\
\hline 6 & $\mathrm{C}$ & 9 & 8 & 7 & 6 & 5 & 4 & 3 & 2 & 1 & 2 & 3 & 4 & 5 & 6 & 7 & 8 & 9 & $\mathrm{D}$ \\
\hline
\end{tabular}

12. The strategic priorities used in improving the quality of SMEs services are:
A. Global Intelligence
B. Work environment
C. Performance self-esteem contingency
D. Behavior of Work

Please mark a cross $(X)$ on the weight scale you want/feel

\begin{tabular}{|c|c|c|c|c|c|c|c|c|c|c|c|c|c|c|c|c|c|c|c|}
\hline 1 & $\mathrm{~A}$ & 9 & 8 & 7 & 6 & 5 & 4 & 3 & 2 & 1 & 2 & 3 & 4 & 5 & 6 & 7 & 8 & 9 & $\mathrm{~B}$ \\
\hline 2 & $\mathrm{~A}$ & 9 & 8 & 7 & 6 & 5 & 4 & 3 & 2 & 1 & 2 & 3 & 4 & 5 & 6 & 7 & 8 & 9 & $\mathrm{C}$ \\
\hline 3 & $\mathrm{~A}$ & 9 & 8 & 7 & 6 & 5 & 4 & 3 & 2 & 1 & 2 & 3 & 4 & 5 & 6 & 7 & 8 & 9 & $\mathrm{D}$ \\
\hline 4 & $\mathrm{~B}$ & 9 & 8 & 7 & 6 & 5 & 4 & 3 & 2 & 1 & 2 & 3 & 4 & 5 & 6 & 7 & 8 & 9 & $\mathrm{C}$ \\
\hline 5 & $\mathrm{~B}$ & 9 & 8 & 7 & 6 & 5 & 4 & 3 & 2 & 1 & 2 & 3 & 4 & 5 & 6 & 7 & 8 & 9 & $\mathrm{D}$ \\
\hline 6 & $\mathrm{C}$ & 9 & 8 & 7 & 6 & 5 & 4 & 3 & 2 & 1 & 2 & 3 & 4 & 5 & 6 & 7 & 8 & 9 & $\mathrm{D}$ \\
\hline
\end{tabular}

13. The strategic priorities used in Improving the Image of SMEs are:
A. Global Intelligence
B. Work environment
C. Performance self-esteem contingency
D. Behavior of Work

Please mark a cross $(X)$ on the weight scale you want/feel

\begin{tabular}{|l|l|l|l|l|l|l|l|l|l|l|l|l|l|l|l|l|l|l|l|}
\hline 1 & $\mathrm{~A}$ & 9 & 8 & 7 & 6 & 5 & 4 & 3 & 2 & 1 & 2 & 3 & 4 & 5 & 6 & 7 & 8 & 9 & $\mathrm{~B}$ \\
\hline 2 & $\mathrm{~A}$ & 9 & 8 & 7 & 6 & 5 & 4 & 3 & 2 & 1 & 2 & 3 & 4 & 5 & 6 & 7 & 8 & 9 & $\mathrm{C}$ \\
\hline 3 & $\mathrm{~A}$ & 9 & 8 & 7 & 6 & 5 & 4 & 3 & 2 & 1 & 2 & 3 & 4 & 5 & 6 & 7 & 8 & 9 & $\mathrm{D}$ \\
\hline 4 & $\mathrm{~B}$ & 9 & 8 & 7 & 6 & 5 & 4 & 3 & 2 & 1 & 2 & 3 & 4 & 5 & 6 & 7 & 8 & 9 & $\mathrm{C}$ \\
\hline 5 & $\mathrm{~B}$ & 9 & 8 & 7 & 6 & 5 & 4 & 3 & 2 & 1 & 2 & 3 & 4 & 5 & 6 & 7 & 8 & 9 & $\mathrm{D}$ \\
\hline 6 & $\mathrm{C}$ & 9 & 8 & 7 & 6 & 5 & 4 & 3 & 2 & 1 & 2 & 3 & 4 & 5 & 6 & 7 & 8 & 9 & $\mathrm{D}$ \\
\hline
\end{tabular}

\section{Appendix A.2. SWOT Questionnaire}

Please mark a cross $(X)$ on the weight scale and assessment that you want/feel 


\begin{tabular}{|c|c|c|c|c|c|c|c|c|c|c|}
\hline \multirow{2}{*}{ No } & \multirow{2}{*}{ Question } & \multicolumn{4}{|c|}{ Score } & \multicolumn{5}{|c|}{ Assessment } \\
\hline & & 1 & 2 & 3 & 4 & 1 & 2 & 3 & 4 & 5 \\
\hline \multicolumn{11}{|c|}{ Internal factors } \\
\hline \multicolumn{11}{|c|}{ Strength } \\
\hline 1 & The quality of our products is recognized by the public & & & & & & & & & \\
\hline 2 & We have a strong brand image & & & & & & & & & \\
\hline 3 & Our products have competitive prices & & & & & & & & & \\
\hline 4 & Our location is quite strategic & & & & & & & & & \\
\hline 5 & Our service is fast and friendly & & & & & & & & & \\
\hline 6 & We have a lot of regular customers & & & & & & & & & \\
\hline \multicolumn{11}{|c|}{ Weakness } \\
\hline 1 & We often overproduce & & & & & & & & & \\
\hline 2 & Our scope of distribution is limited & & & & & & & & & \\
\hline 3 & Our promotional activities are still lacking & & & & & & & & & \\
\hline 4 & The quality of our human resources is still low & & & & & & & & & \\
\hline 5 & We lack the capital for business development & & & & & & & & & \\
\hline \multirow{2}{*}{ No } & \multirow{2}{*}{ Question } & \multicolumn{4}{|c|}{ Score } & \multicolumn{5}{|c|}{ Assessment } \\
\hline & & 1 & 2 & 3 & 4 & 1 & 2 & 3 & 4 & 5 \\
\hline \multicolumn{11}{|c|}{ External Factors } \\
\hline \multicolumn{11}{|c|}{ Opportunity } \\
\hline 1 & Our product can be unique souvenirs & & & & & & & & & \\
\hline 2 & Our market share is wide & & & & & & & & & \\
\hline 3 & We have good relationships with fellow entrepreneurs & & & & & & & & & \\
\hline 4 & Advances in technology help our sales & & & & & & & & & \\
\hline 5 & We have abundant raw materials & & & & & & & & & \\
\hline \multicolumn{11}{|c|}{ Threat } \\
\hline 1 & Shifts in people's consumption affect our sales & & & & & & & & & \\
\hline 2 & The scope of distribution of competitors is wider & & & & & & & & & \\
\hline 3 & There are new competitors & & & & & & & & & \\
\hline 4 & Competitor prices are cheaper & & & & & & & & & \\
\hline
\end{tabular}

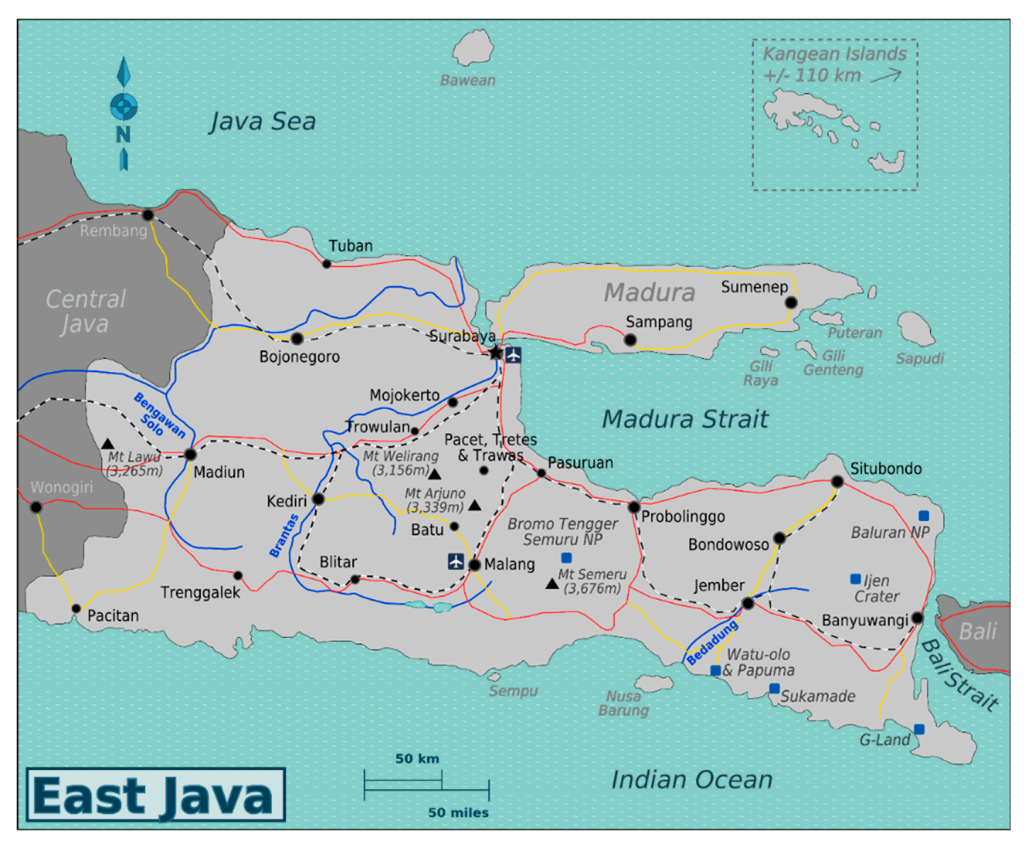

Figure A12. East Java. 


\section{References}

1. Rotge, V. Rural Urban Integration in Java: Consequences for Regional Development and Employemnt: Consequences for Regional Development and Employemnt; Routledge: London, UK, 2018.

2. Sofield, T.H. Empowerment for Sustainable Tourism Development; Emerald Group Publishing: West Yorkshire, UK, 2003.

3. Syapsan, S. The effect of service quality, innovation towards competitive advantages and sustainable economic growth: Marketing mix strategy as mediating variable. Benchmarking Int. J. 2019, 26, 1336-1356. [CrossRef]

4. Campón-Cerro, A.M.; Hernández-Mogollón, J.M.; Alves, H. Sustainable improvement of competitiveness in rural tourism destinations: The quest for tourist loyalty in Spain. J. Destin. Mark. Manag. 2017, 6, 252-266. [CrossRef]

5. Hermawati, A. Transglobal leadership approach to sustainable tourism competitiveness at tourism sector-engaged MSMEs through integrated human resource performance and responsible marketing. Int. J. Tour. Cities 2020, 6, 863-883. [CrossRef]

6. Moeuf, A.; Lamouri, S.; Pellerin, R.; Tamayo-Giraldo, S.; Tobon-Valencia, E.; Eburdy, R. Identification of critical success factors, risks and opportunities of Industry 4.0 in SMEs. Int. J. Prod. Res. 2020, 58, 1384-1400. [CrossRef]

7. Luo, X. Self-Empowerment and Its Discontents-Shanghai Private Art Museums in Contemporary China; The Chinese University of Hong Kong: Hong Kong, China, 2019.

8. Hermawati, A. Identify strategies for cooperatives in East Java with analytic hierarchical process. Int. J. Dev. Issues 2020, 19, 103-117. [CrossRef]

9. Badran, B.; Badran, N.B. Strategic Networks and Alliances among Tourism MSMEs: The Case of Dubai's "Wander with"; Piccola Impresa/Small Business, 2019; Available online: http://rivistapiccolaimpresa.uniurb.it/ index.php/piccola/article/view/313 (accessed on 1 November 2020).

10. Laužikas, M.; Tvaronavičienè, M. Human resource management effects on sustainability of high-tech companies: What Lithuania and South Korea can learn from each other. Insights Reg. Dev. 2020, 2, 562-579. [CrossRef]

11. Mao, H.; Liu, S.; Zhang, J.; Deng, Z. Information technology resource, knowledge management capability, and competitive advantage: The moderating role of resource commitment. Int. J. Inf. Manag. 2016, 36, 1062-1074. [CrossRef]

12. Ancillai, C.; Terho, H.; Cardinali, S.; Pascucci, F. Advancing social media driven sales research: Establishing conceptual foundations for B-to-B social selling. Ind. Mark. Manag. 2019, 82, 293-308. [CrossRef]

13. Sawaneh, I.A.; Kamara, F.K. An Effective Employee Retention Policies as a Way to Boost Organizational Performance. J. Hum. Resour. Manag. 2019, 7, 41-48. [CrossRef]

14. Hermawati, A.; Suhermin, P.R. The transglobal leadership-based strategy of MSMEs performance optimization of Malang Raya and the implementation of quality of work life. Res. J. Text. Appar. 2019, 23, 38-57. [CrossRef]

15. Saadati, M.; Tabrizi, J.S.; Rezapour, R.; Kalajahi, R.A. Home injury prevention attitude and performance: A community-based study in a designated safe community. J. Inj. Violence Res. 2020, 12, 145.

16. Ahmad, I.; Danish, R.Q.; Ali, S.A.; Ali, H.F.; Humayon, A.A. A Comparative Study of Banking Industry Based on Appraisal System, Rewards and Employee Performance. SEISENSE J. Manag. 2018, 2, 1-11. [CrossRef]

17. Eliyana, A.; Ma'Arif, S. Muzakki Job satisfaction and organizational commitment effect in the transformational leadership towards employee performance. Eur. Res. Manag. Bus. Econ. 2019, 25, 144-150. [CrossRef]

18. Clark, C.S. Social Processes in Work Groups: A Model of the Effect of Involvement, Credibility, and Goal Linkage on Training Success. Ph.D. Thesis, University of Tennessee, Knoxville, TN, USA, 1990.

19. $\mathrm{Ru}, \mathrm{Y}$. Mediating roles of intrinsic motivation and self-efficacy in the relationships between perceived person-job fit and work outcomes. Afr. J. Bus. Manag. 2012, 6, 2616-2625.

20. Porter, L.; Lawler, E. Managerial Attitudes and Performance Homewood, IL; Irwin. psychological empowerment on job performance: The mediating effects of organizational citizenship behavior. Int. J. Hosp. Manag. 1968, 31, 180-190.

21. Smith, C.; Organ, D.W.; Near, J.P. Organizational citizenship behavior: Its nature and antecedents. J. Appl. Psychol. 1983, 68, 653. [CrossRef] 
22. Podsakoff, P.M.; MacKenzie, S.B.; Bommer, W.H. Transformational Leader Behaviors and Substitutes for Leadership as Determinants of Employee Satisfaction, Commitment, Trust, and Organizational Citizenship Behaviors. J. Manag. 1996, 22, 259-298. [CrossRef]

23. Alotaibi, A.G. Antecedents of Organizational Citizenship Behavior: A Study of Public Personnel in Kuwait. Public Pers. Manag. 2001, 30, 363-376. [CrossRef]

24. Biswas, S. Impact of psychological climate \& transformational leadership on employee performance. Indian J. Ind. Relat. 2012, 48, 105-119.

25. Sageer, A.; Rafat, S.; Agarwal, P. Identification of variables affecting employee satisfaction and their impact on the organization. IOSR J. Bus. Manag. 2012, 5, 32-39. [CrossRef]

26. Yukl, G.; Mahsud, R.; Prussia, G.; Hassan, S. Effectiveness of broad and specific leadership behaviors. Pers. Rev. 2019, 48, 774-783. [CrossRef]

27. Kundu, S.C.; Kumar, S.; Gahlawat, N. Empowering leadership and job performance: Mediating role of psychological empowerment. Manag. Res. Rev. 2019, 42, 605-624. [CrossRef]

28. Lee, G.R.; Lee, S.; Malatesta, D.; Fernandez, S. Outsourcing and Organizational Performance: The Employee Perspective. Am. Rev. Public Adm. 2019, 49, 973-986. [CrossRef]

29. Beinö, O.; Alexanderson, L. Impact of Green Marketing on Consumer Behaviour: A Case Study on the Furniture Industry. Bachelor's Thesis, Jönköping International Business School, Jönköping, Sweden, 2020.

30. Chandran, C.; Bhattacharya, P. Hotel's best practices as strategic drivers for environmental sustainability and green marketing. J. Glob. Sch. Mark. Sci. 2019, 29, 218-233. [CrossRef]

31. Laeis, G. What's on the Menu? How the Cuisine of Large-Scale, Upmarket Tourist Resorts Shapes Agricultural Development in Fiji. Ph.D. Thesis, Massey University, Manawatū, New Zeeland, 2019.

32. Martínez, J.M.G.; Martín, J.M.M.; Fernández, J.A.S.; Mogorrón-Guerrero, H. An analysis of the stability of rural tourism as a desired condition for sustainable tourism. J. Bus. Res. 2019, 100, 165-174. [CrossRef]

33. Estêvão, R.S.; Ferreira, F.A.; Rosa, Á.A.; Govindan, K.; Meidutè-Kavaliauskienė, I. A socio-technical approach to the assessment of sustainable tourism: Adding value with a comprehensive process-oriented framework. J. Clean. Prod. 2019, 236, 117487.

34. Neacsu, M.N.; Platon, O.E. Using SWOT analysis to substantiate marketing strategies for balneo-tourism. New Trends Issues Proc. Humanit. Soc. Sci. 2019, 6, 30-38. [CrossRef]

35. Liu, J.; Wang, C.; Fang, S.; Zhang, T.C. Scale development for tourist trust toward a tourism destination. Tour. Manag. Perspect. 2019, 31, 383-397. [CrossRef]

36. Wray, M.; Dredge, D.; Cox, C.; Buultjens, J.; Hollick, M.; Lee, D.; Pearlman, M.; Lacroix, C. Sustainable Regional Tourism Destinations: Best Practice for Management, Development and Marketing; CRC for Sustainable Tourism: Gold Coast, Australia, 2010.

37. Cortez, R.M.; Johnston, W.J. Marketing role in B2B settings: Evidence from advanced, emerging and developing markets. J. Bus. Ind. Mark. 2019, 34, 605-617. [CrossRef]

38. Dangelico, R.M.; Vocalelli, D. "Green Marketing": An analysis of definitions, strategy steps, and tools through a systematic review of the literature. J. Clean. Prod. 2017, 165, 1263-1279. [CrossRef]

39. Miles, M.P.; Covin, J.G. Environmental Marketing: A Source of Reputational, Competitive, and Financial Advantage. J. Bus. Ethics 2000, 23, 299-311. [CrossRef]

40. Coddington, W. Environmental marketing's new relationship with corporate environmental management. Environ. Qual. Manag. 1993, 2, 297-302. [CrossRef]

41. Ottman, J.A. Industry's response to green consumerism. J. Bus. Strategy 1992, 13, 3-7. [CrossRef] [PubMed]

42. Yun, J.J.; Won, D.; Park, K. Entrepreneurial cyclical dynamics of open innovation. J. Evol. Econ. 2018, 28, 1151-1174. [CrossRef]

43. Fleming, L.; Waguespack, D.M. Penguins, camels, and other birds of a feather: Brokerage, boundary spanning, and leadership in open innovation communities. SSRN Electron. J. 2005. Available online: http://dx.doi.org/10.2139/ssrn.710641 (accessed on 1 November 2020).

44. Podmetina, D.; Volchek, D.; Dabrowska, J.; Fiegenbaum, I. Human resource practices and open innovation. Int. J. Innov. Manag. 2013, 17, 1340019. [CrossRef] 
45. Yun, J.J.; Liu, Z. Micro- and Macro-Dynamics of Open Innovation with a Quadruple-Helix Model. Sustainability 2019, 11, 3301. [CrossRef]

46. Yun, J.J.; Zhao, X.; Jung, K.; Yigitcanlar, T. The culture of open innovation dynamics. Sustainability 2020, $12,5076$. [CrossRef]

Publisher's Note: MDPI stays neutral with regard to jurisdictional claims in published maps and institutional affiliations.

(C) 2020 by the authors. Licensee MDPI, Basel, Switzerland. This article is an open access article distributed under the terms and conditions of the Creative Commons Attribution (CC BY) license (http://creativecommons.org/licenses/by/4.0/). 